\title{
The Yen Exchange Rate and the Hollowing Out of the Japanese Industry
}

\author{
Ansgar Belke ${ }^{1,2,3,4} \cdot$ Ulrich Volz ${ }^{5}$
}

Published online: 18 January 2020

(C) The Author(s) 2020

\begin{abstract}
Since the demise of the Bretton Woods system, the yen has seen several episodes of strong appreciation, including in the late 1970s, after the 1985 Plaza Agreement, the early and late 1990 s and after 2008 . These appreciations have not only been associated with "expensive yen recessions" resulting from negative effects on exports; since the late 1980s, the strong yen has also raised concerns about a de-industrialisation of the Japanese economy. Against this backdrop, the article investigates the effects of changes to the yen exchange rate on the hollowing out of the Japanese industrial sector. To this end, the article uses both aggregate and industry-specific data to gauge the effects of yen fluctuations on the output and exports of different Japanese industries, exploiting new data for industry-specific real effective exchange rates. Our findings support the view that the periods of yen appreciation had more than just transitory effects on Japanese manufacturing. The results also provide indication of hysteresis effects on manufacturing. While there are certainly also other factors that have contributed to a hollowing out of Japanese industry, a strong yen played a role, too.
\end{abstract}

Keywords Yen appreciation · Exchange rates · Japanese manufacturing · Hollowing out · Hysteresis

JEL Classification F31 $\cdot \mathrm{O} 14$

\section{Introduction}

A strong yen - endaka (円高) in Japanese - has repeatedly caused distress among Japanese policymakers and manufacturers. Since the demise of the Bretton Woods

Ulrich Volz

uv1@soas.ac.uk

Ansgar Belke

ansgar.belke@uni-due.de

Extended author information available on the last page of the article 
system in 1971, the yen has seen several episodes of strong appreciation, including in the late 1970s, after the 1985 Plaza Agreement, the early and late 1990s and after 2008 (Fig. 1). These appreciations have not only been associated with "expensive yen recessions" - endaka fukyo (円高不況) in Japanese - resulting from negative effects on exports; since the late 1980s, the strong yen has also raised concern about a deindustrialisation of the Japanese economy. Indeed, the share of manufacturing in total output has declined from $26.7 \%$ in 1980 to $20.5 \%$ in 2015 , while the share of manufacturing in total number of employed persons has declined from $27.0 \%$ to $16.2 \%$ between 1970 and 2016 (Fig. 2). The decline in the share of manufacturing in total employment or GDP is not unique to Japan. It is indeed a phenomenon that can be seen across industrialised economies, with varying degrees. What makes Japan a particularly interesting case to analyse is that the yen's real effective exchange rate has shown much larger volatility than the currencies of other large advanced economies. Between 1980 and 2018, the standard deviation of Japan's annual real effective exchange rate was 17.0, compared to 12.3 for the U.S., 10.4 for the United Kingdom, and 5.3 for Germany. Exchange rate effects on manufacturing may therefore have been more pronounced than elsewhere.

While the strong yen and its potentially de-industrialising effect have received much attention in the political and economic policy discourse in Japan, there has been surprisingly little research on this in the academic literature. As pointed out by Hamada and Okada (2009: 200), most research on Japan's "lost decade" and hollowing out of the Japanese industry "have been broadly focused on its real and domestic aspects, such as total factor productivity (TFP), growth decline, non-performing loans, and

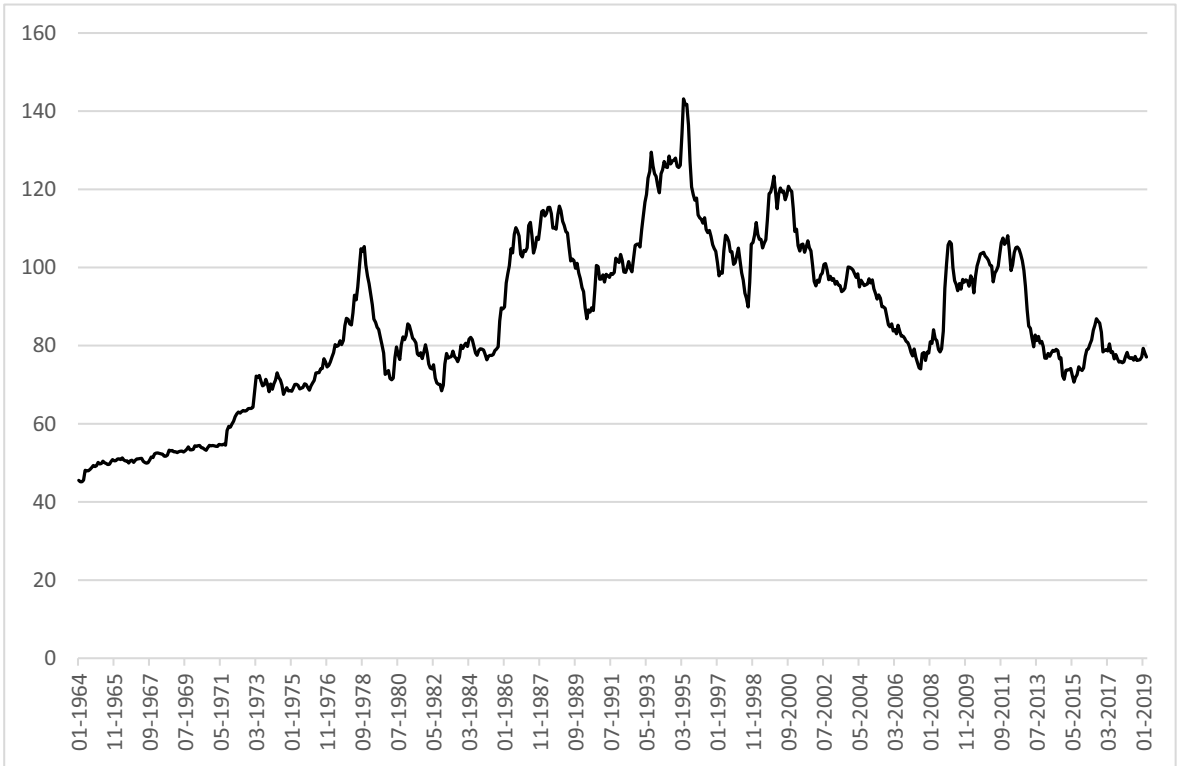

Source: Compiled by authors with data from the BIS Effective Exchange Rate Indices (Monthly data: Narrow indices, updated 17 April 2019), www.bis.org/statistics/eer.htm.

Fig. 1 Real effective exchange rate of the Japanese yen, 1964-2019 $(2010=100)$ 


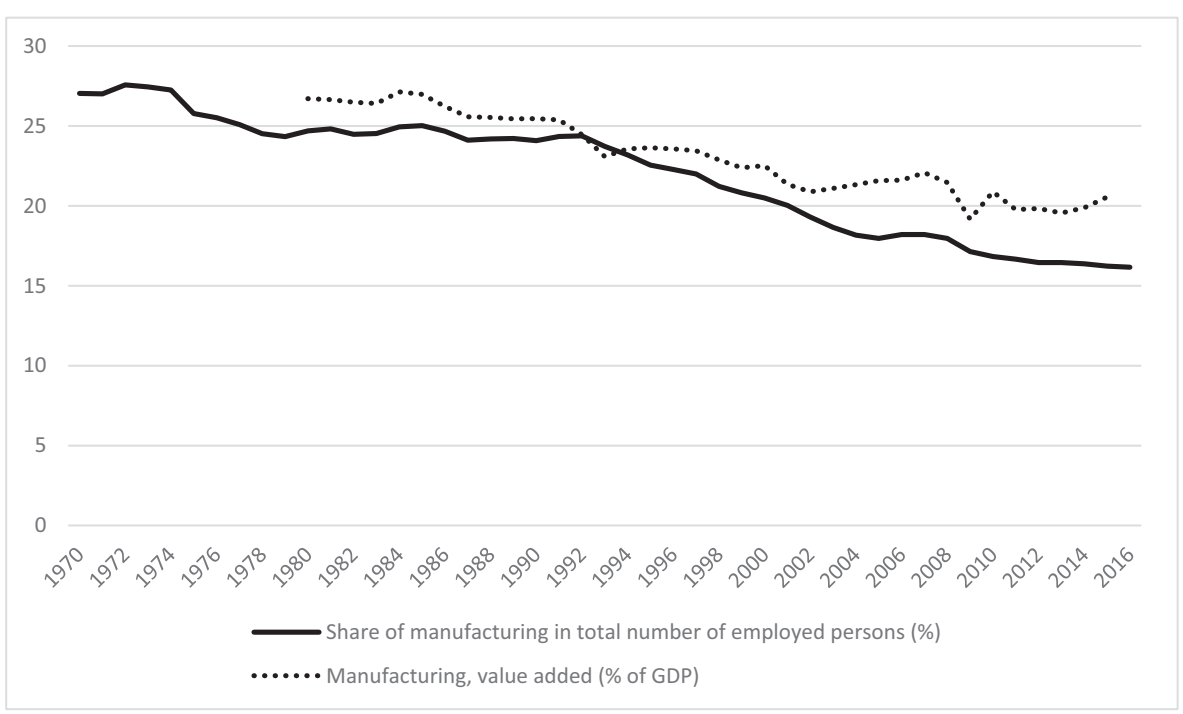

Source: Compiled by authors with data from the Japan Labor Force Survey and the World Development Indicators.

Fig. 2 Value added in manufacturing as share of GDP and share of manufacturing in total number of employed persons

governance." Hamada and Okada (2009: 200) argue that monetary and exchange rate policy have played an important role in this, and that "Japanese industries endured a heavy burden" due to a greatly overvalued real exchange rate.

Against this backdrop, the article aims to investigate the effects of yen fluctuations on industrial production and the hollowing out of the Japanese industry. The major contribution of this study is an econometric analysis using new data for industryspecific real effective exchange rates (RIETI 2018) to gauge the effects of yen fluctuations on the output and exports of different Japanese industries at monthly frequency. As recently shown by Fort et al. (2018) for the US economy, changes to manufacturing employment have differed considerably across sectors. The use of monthly, industry-specific data allows us to better capture potential effects of real effective exchange rate movements. We also use annual data since 1970 to investigate potential long-term effects of yen exchange rate changes on manufacturing employment. Following Rowthorn and Coutts (2004: 767), we define de-industrialisation - to which we also refer as "hollowing out" - as "a secular decline in the share of manufacturing in national employment".

The topic is not only of relevance to the Japanese economy, it also bears relevance for other advanced economies. Indeed, recent years have seen an intense discussion in several member countries of the Eurozone about purported negative effects of a too high euro exchange rate on manufacturing and employment (e.g., Belke and Volz 2015). For instance, Bénassy-Quéré et al. (2014: 7) estimate that for France "a 10\% depreciation in the euro in relation to a partner country outside the eurozone increases the value of the average exporter's sales to this country by around 5-6\%", with most of this effect realised in the same year as the depreciation. Likewise, the U.S. has recently 
seen a renewed discussion on de-industrialisation, with a prominent role of the dollar exchange rate in this discourse (e.g., Campbell 2017; Levinson 2017). A better understanding of any exchange rate effects on Japanese manufacturing should also provide insights for economic and monetary policy elsewhere.

The reminder of the article is structured as follows. Section 2 provides a review of the literature on the effects of exchange rate changes on de-industrialisation. Section 3 comprises our empirical analysis. The empirical part is split into two sections: Firstly, we conduct an empirical analysis with annual, aggregate data from 1970 to 2016 that allows us to investigate potential long-term effects of yen exchange rate changes on manufacturing employment. Secondly, we use monthly, industry-specific data from January 2001 to June 2017 to gauge the dynamics of yen exchange rate changes on Japanese sectoral manufacturing employment. Section 4 summarises and concludes.

\section{Literature Review}

It is well established that depreciated real exchange rates can help to stimulate industrial development and economic growth (Rodrik 2008). ${ }^{1}$ Although there seems to exist a "fear of appreciation" (Levy-Yeyati et al. 2013) relatively little research has been conducted on the effect of overvalued exchange rates on economies. The first systematic empirical cross-country analysis to investigate the effects of large exchange rate appreciation on current account balances and on real output was conducted by Kappler et al. (2013), who find that episodes of strong exchange rate appreciations are associated with deteriorating current account balances and a slow-down of real export growth, but no significant effects on output. Likewise, Bussière et al. (2015) examine to what extent large and rapid real exchange rate appreciations impact on economic growth. Using a sample of 53 emerging and advanced economies, they find that while large appreciations dampen export growth and boost import growth, output growth is higher on average.

The literature on de-industrialisation has focused less on exchange rate valuations than on changes in specialisation, consumption, technological progress and productivity, international trade and investment patterns (Rowthorn and Coutts 2004). The major exemption is the U.S. economy, for which the effect of the dollar exchange rate on the U.S. industry has been studied widely. The findings in this literature are mixed, with some studies finding a large effect (Branson and Love 1986, 1987, 1988a, b; Revenga 1992; Gourinchas 1999; Kandil and Mirzaie 2002, 2003; Klein et al. 2003; Campbell 2017) and others a small or no impact (Glick and Hutchison 1990; Goldberg 1993; Campa and Goldberg 1995, 2001; Bahmani-Oskooee and Mirzaie 2000; BahmaniOskooee et al. Bahmani-Oskooee et al. 2007). ${ }^{2}$

\footnotetext{
${ }^{1}$ A recent study by Alfaro et al. (2018) confirms this for economies with high export participation.

2 There are also a number of studies investigating exchange rate effects on European economies. For instance, using firm-level data, Moser et al. (2010) and Berman et al. (2012) find relatively small exchange rate effects on employment of German and French firms, respectively. Ekholm et al. (2012) analyse the impact of a real appreciation of the Norwegian krona on Norwegian net-exporting and import-competing firms in the early 2000 s, finding negative effects on domestic employment across both groups of firms. Thorbecke and Kato (2017) examine the effect of changes to the Swiss franc exchange rate on the Swiss economy and find differences related to the sophistication of exports.
} 
According to Rowthorn and Ramaswamy (1997a, b) and Rowthorn and Coutts (2004, 2013), the most important internal/domestic factors contributing to deindustrialisation are productivity growth in the manufacturing sector and shifting patterns of domestic expenditure, i.e., with rising income consumption tends to shifts towards more services and away from manufactured goods (known as Engel's Law or Bell's Law). The most important external factors are identified as "North-South" trade and the outsourcing of labour-intensive manufacturing to low-wage countries. However, domestic factors, especially a higher productivity growth in manufacturing than in services, are widely seen as the dominant factor behind de-industrialisation (Rowthorn and Ramaswamy 1997a, b; Rowthorn and Coutts 2004, 2013; Lawrence 2017). ${ }^{3}$

Surprisingly few studies have looked into the potentially de-industrialising effect of endaka, even though Obstfeld (2010) pointed out that Japan's real economic growth rate has been strongly negatively correlated with the level of the yen's real effective exchange rate. Only few studies can be found that systematically try to verify the hypothesis that the strong yen has contributed to de-industrialisation and outsourcing of industry in Japan, including Dekle (1996), Dekle et al. (2010) and Yamashita (2013, 2015). Dekle (1996) and Dekle et al. (2010) find that yen appreciations of 1985 and 1995 significantly hurt the ability of Japan to compete with the U.S. by raising the relative production costs of Japanese industries. Yamashita $(2013,2015)$ finds that yen appreciation and outward FDI contributed to de-industrialisation and suggests that a weak yen may contribute to reshoring. ${ }^{4}$

A string of studies examines the role of Japanese outward direct investment in the hollowing out process. Japanese outward direct investment took off in the mid-1980s (Fukao et al. 2003). The number of Japanese multinationals increased by $290 \%$ between 1985 and 1992, while overseas production of Japanese firms increased from $3 \%$ in 1982 to $17 \%$ in 2002 (Ryan and Toubal 2017). Analysing data on Japanese acquisitions in the United States from 1975 to 1992, Bloningen (1997) finds that real dollar depreciations increased the likelihood of Japanese acquisitions in U.S. industries. Likewise, the BOJ (2011) attributed the renewed shifting of production abroad since 2008 to the relative appreciation of the yen compared to the levels before the Lehman shock.

Empirically, the effect of outsourcing on domestic manufacturing employment is mixed. According to Baldwin (2006), offshoring labour-intensive production processes to adjacent lower-cost locations in Southeast and Northeast Asia since the mid-1980s did apparently allow Japanese companies to retain parts of manufacturing production domestically while maintaining international competitiveness. The BOJ (1989) finds that increased outward direct investment contributed to long-term structural adjustment in the export sector. This contributed to a temporary surge in the export of capital goods and parts to overseas production

\footnotetext{
${ }_{3}$ A further factor that appears to have played a role in the falling share of manufacturing is the outsourcing of various services that historically were conducted in-house and hence counted as manufacturing, whereas they are now counted as services. See Boulhol and Fontagné (2006). Evidence for this development in Japan is presented in Uemura and Tahara (2014).

${ }^{4}$ Bleaney (1997) looks at the pricing of Japanese manufacturing exports and finds a significant role of the yen real exchange rate.
} 
bases of Japanese companies. Yamashita and Fukao (2010) find no indication that expansion of overseas operations by Japanese manufacturing multinational enterprises reduced home employment over the period 1991-2002; indeed, their analysis suggests that it may have contributed to maintaining the level of home employment. A recent study by Ryan and Toubal (2017) uses Japanese firmlevel data for the period 1982-2001 to compare employment between firms with and without foreign affiliates and the extent to which the development of foreign operations affects firm-level domestic employment. It finds "some limited evidence" of the hollowing out of the Japanese economy by Japanese multinational firms shifting production abroad from 1991 onwards.

Using the same industry-specific exchange rates that will be employed in our empirical analysis later, Sato et al. (2013) analyse export price competitiveness and export performance of Japan, China and Korea and find that the strong yen after 2007 destroyed the Japanese electronics sector. Likewise, Thorbecke (2012) finds in a study focused on the Japanese electronics industry that the yen appreciation between 2007 and 2011 had a very damaging effect on electronics exports. However, neither study controls for employment effects. Kato (2018) examines the effects of exchange rate changes and productivity on manufacturing exports for the period 2002-2012 and finds exchange rates to be important factors to affect firm-level exports.

An important issue in this context is that exchange rate appreciations and depreciations may not have symmetrical effects. That is, a period of strong appreciation may lead to outsourcing and the loss of manufacturing capacities - and employment - in the home country, but a depreciation later on may not bring about a return (or "re-shoring") of manufacturing activities and employment, given that long-term investments have been made abroad, which will not be reversed. These hysteresis effects have been described in sunk cost models of trade hysteresis (Krugman 1988; Baldwin and Krugman 1989; Baldwin 1990; Baldwin and Lyons 1994) and empirically investigated mostly for the U.S. and a number of European economies. ${ }^{5}$ Giovannetti and Samiei (1995) conduct an empirical analysis of the importance of hysteresis in international trade, using manufacturing exports for the United States, Germany, and Japan. They find "strong evidence" in favour of the presence of hysteresis only in the case of Japanese exports.

\section{Empirical Approach and Findings}

For our econometric analysis, we use both aggregate and industry-specific data to gauge the effects of changes of the real effective yen exchange rate. Taking account of the availability of different data series, we firstly conduct an empirical analysis with annual data from 1970 to 2016 that allows us to investigate potential long-term effects of yen exchange rate changes on manufacturing employment. Secondly, we use monthly data from 2001:M01 to 2017:M06 to check the dynamics of yen exchange rate changes on Japanese sectoral manufacturing employment, exploiting a new monthly dataset on Japanese sectoral exchange rates which are only available from 2001 onwards. For this purpose, we use a mixed time series-panel framework.

\footnotetext{
${ }^{5}$ See Belke et al. (2013), Belke and Kronen (2019), Campa (2004) and Campbell (2017).
} 


\subsection{Analysis with Annual Data, 1970-2016}

\subsubsection{Data and Empirical Model}

Building on Rowthorn and Ramaswamy (1997a) and Rowthorn and Coutts (2004, 2013), we estimate the following model for Japan and annual data ranging from 1970 to $2016^{6}$ :

$$
\begin{aligned}
\text { EMPMAN }= & \beta_{0}+\beta_{1} \text { EMPMAN }_{t-1}+\beta_{2} \text { CAP }+\beta_{3} \text { EXPMAN }+\beta_{4} \text { OFDI } \\
& +\beta_{5} \text { TFP }+\beta_{6} \text { EXPCHIN }+\beta_{7} \text { EXR }+\varepsilon,
\end{aligned}
$$

with EMPMAN = Share of manufacturing in the total number of employed persons (\%), $C A P=$ Gross domestic fixed capital formation (\% of GDP), EXPMAN = Manufacturing exports, $O F D I=$ Outward direct investment, $T F P=$ Total factor productivity at constant national prices, $E X P C H I N=$ Chinese exports, and $E X R=$ Real effective exchange rate. Appendix Table 14 provides more details on the variables and sources.

The selection of explanatory variables in (1) is motivated by the standard variables used in previous studies on de-industrialisation. To these we add EXR as the variable of our particular interest to investigate the hypothesis that movements of the yen's real effective exchange rate have contributed to a de-industrialisation of the Japanese economy.

Increases in fixed capital formation could theoretically have both positive and negative effects on manufacturing employment. On the one hand, an increased investment in the domestic manufacturing sector could have positive employment effects. On the other hand, however, capital investment could advance the automation of manufacturing production, with neutral or even negative effects on manufacturing employment. In contrast, an increase in manufacturing exports should clearly have a positive effect on domestic manufacturing employment. As discussed above, the effect of outward direct investment can be ambiguous: on the one hand a shifting of production abroad may have negative employment effects, but at the same time there could be positive outcomes because it may increase the competitiveness of domestic operations which would remain important parts of regional or global value chains (Baldwin 2006; Yamashita and Fukao 2010).

As mentioned above, productivity increases have been identified in the deindustrialisation literature as a major factor behind the fall in manufacturing employment, so we would expect a negative coefficient. We use TFP as our measure of productivity. We considered using alternative measures of productivity, such as multifactor productivity, but were not able to obtain data ranging back to the 1970 s.

The effects of Chinese export growth are, again, ambiguous. ${ }^{7}$ While Chinese export growth is a reflection of China's rapid growth process, which has also opened up great opportunities for Japanese companies, Chinese exporters have increasingly become

\footnotetext{
${ }^{6}$ The same framework is applied by Boulhol and Fontagné (2006), who analyse the change in the share of manufacturing in employment between 1970 and 2002 for 16 OECD countries. But none of these studies controls for exchange rate effects.

${ }^{7}$ Unfortunately, no data was available for Chinese manufacturing exports for this period. This is why we selected total exports from China.
} 
competitors of Japanese manufacturing firms. Last but not least, we would expect the coefficient estimate for the real effective exchange rate - our main variable of interest to be negative if the hollowing out hypothesis were to hold.

Figure 3 graphically displays the time series of the variables used in our estimations based on annual data. It conveys a first impression of the stationarity properties of the time series used. At first glance, all time series appear to contain, probably stochastic, trends. We will explicitly check for stochastic trends before we start our estimation exercise in order to make sure that the stochastic properties of the included variables meet the standard assumptions of our regression analysis. Moreover, some first indications of correlations can be derived as well. Whether this means "causation" in an econometric sense will be checked later on in this section.

The top left panel of Fig. 3 shows the two main variables of interest, the share of manufacturing in total number of employed persons and the real effective exchange rate. Between 1970 and the mid-1990s, the real effective exchange rate showed a clear long-term appreciation trend, but with two periods - 1978-1982 and 1988-1990 - of depreciation. After a peak in 1995, the real effective exchange rate then shows a

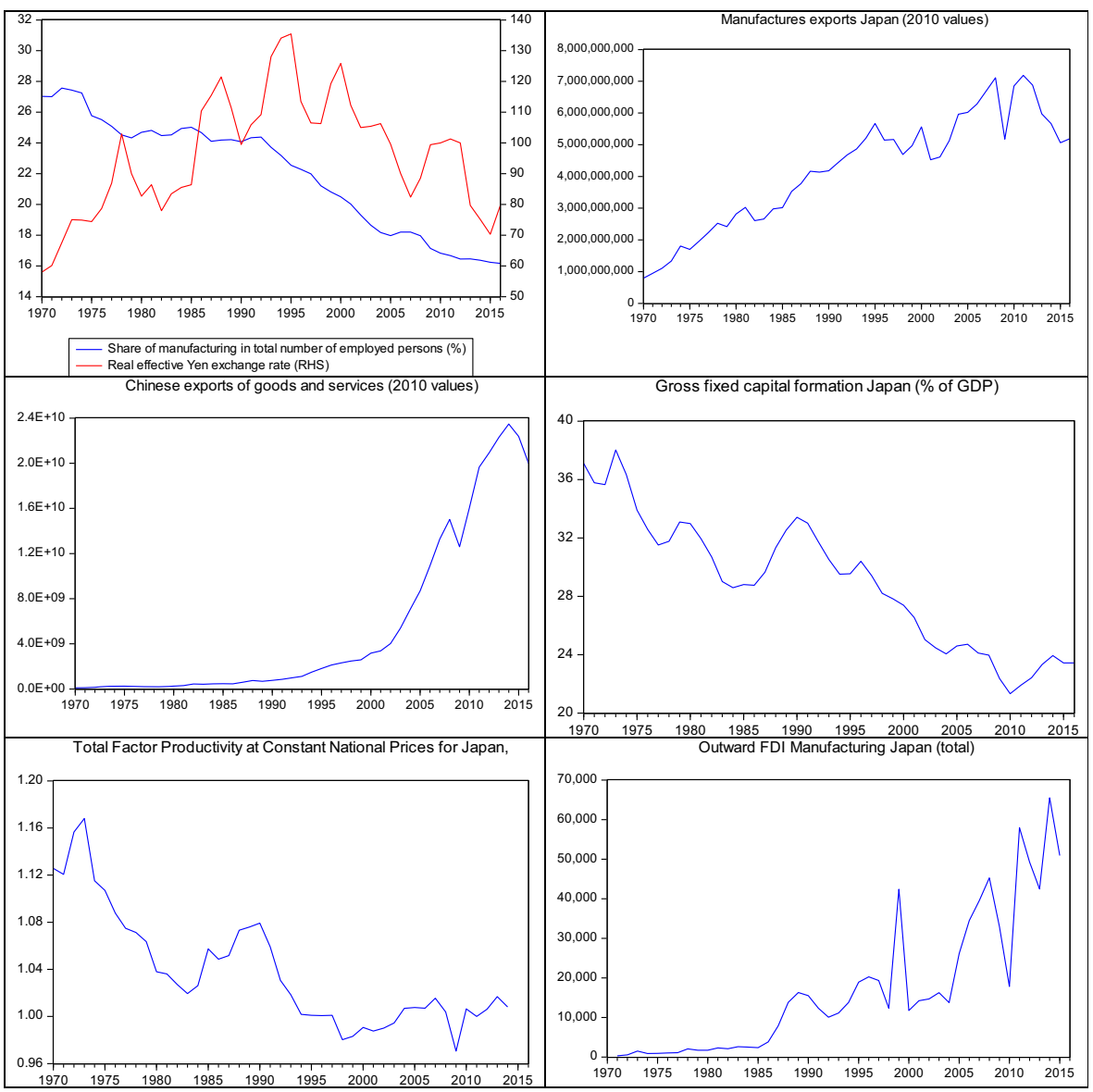

Source: Compiled by authors.

Fig. 3 Variables for analysis with annual data 
declining trend, albeit with periods of strong appreciation in 1998-2000, 2007-2011 and 2015-2016. Over the entire sample period, the share of manufacturing in total number of employed persons shows a long-term declining trend, although the share of manufacturing remains stable over the periods 1987-1992, 2005-2007 and 2012-2016.

\subsubsection{Unit Root Tests}

We proceed with unit root tests of the variables to be employed in our empirical model. The results of our single time series unit root tests are displayed in Table 1. All variables turn out to be integrated of order one (I(1)), except Chinese exports EXPCHIN which appears borderline I(2).

For the real effective yen exchange rate (EXR), with exception of the ADF-test, all complementary unit root tests including the Dickey-Fuller GLS (ERS) test, the PhillipsPerron test, the Kwiatowski-Phillips-Schmidt-Shin test and the Ng-Perron unit root test point into the direction of an I(1) process. Hence, we proceed with the yen exchange rate considering it as an I(1) variable. The results are available on request.

As a robustness check, we also conducted Dickey-Fuller GLS tests, Phillips-Perron tests, Kwiatkowski-Phillips-Schmidt-Shin (KPSS) and Ng-Perron unit root tests not only for the yen exchange rate but also for all other variables. The results overall stayed the same. Among others, they support treating EXPCHIN finally as an I(1) variable in our regressions.

Given the unit root tests conducted in this section and their rather unambiguous results, we feel legitimised to employ the levels of the variables in the framework of a cointegration approach (option 1) and/or use the first differences of all variables as stationary variables in our Autoregressive Distributed Lag (ARDL) estimations (option 2).

Regarding our regression analysis two issues come to mind. Firstly, there is a relatively broad consensus in the literature that one may well find impacts of exchange rate changes on employment even if there is less evidence of an impact on trade (Belke and Gros 2001). Secondly, a thorough regression analysis is necessary to consider leads and lags of the variables when it comes to establish any one-way "causation". This is

Table 1 Results of unit root tests (ADF test statistics and probabilities)

\begin{tabular}{llll}
\hline Variable & Level & First difference & Integration order of variable \\
\hline CAP & $-1.33(0.6087)$ & $-4.96(0.0002)$ & $\mathrm{I}(1)$ \\
EMPMAN & $-0.56(0.8680)$ & $-4.69(0.0004)$ & $\mathrm{I}(1)$ \\
EXPCHIN & $2.52(1.0000)$ & $-0.59(0.9735)$ & $\mathrm{I}(1) / \mathrm{I}(2)$ \\
EXPMAN & $-1.92(0.3195)$ & $-8.10(0.0000)$ & $\mathrm{I}(1)$ \\
EXR & $-2.75(0.0088)$ & $-5.20(0.0001)$ & $\mathrm{I}(1)$ \\
OFDI & $0.45(0.9827)$ & $-8.23(0.0000)$ & $\mathrm{I}(1)$ \\
TFP & $-1.83(0.3629)$ & $-6.17(0.0000)$ & $\mathrm{I}(1)$ \\
\hline
\end{tabular}

Source: Compiled by authors

Table displays empirical realisations of the Augmented Dickey-Fuller test with a constant (MacKinnon (1996) one-sided p-values) 
dramatically shown by the main results of the export hysteresis literature which shows that a positive coefficient of the exchange rate in export, employment, investment or industrial output equations may just hide a more complex dynamic of the relationship which may include stepwise negative effects of an appreciation of the home currency (Krugman and Baldwin 1987; Belke et al. 2013). ${ }^{8}$

We now turn to the first option, the estimation of a cointegrating equation in order to assess the impact of the yen exchange rate (EXR) on the share of manufacturing in total number of employed persons in Japan (EMPMAN), taking the other variables contained in eq. (1) into account simultaneously in the long-run relationship.

\subsubsection{A Cointegration Approach: In Search of Long-Run "Causation" of "Hollowing out"}

As our cointegration framework we choose Dynamic Ordinary Least Squares (DOLS). This is because DOLS allows us to test for causality running from the independent to the dependent variables. The DOLS estimation technique controls for endogeneity of explanatory variables (Stock and Watson 1993; Wooldridge 2009). Endogeneity in the form of feedback effects or reverse causality between the dependent and independent variables would lead to a misspecification of our estimated models. More specifically, the DOLS procedure controls for endogeneity of all explanatory variables by inserting leads and lags of the changes of all exogenous variables. Hence, DOLS is a powerful estimation technique, where standard errors are corrected for heteroscedasticity and cross-section correlation (Saikkonen 1992; Stock and Watson 1993). By inserting the leads and lags of the exogenous variables in first differences, the explanatory variables in levels become (super-) exogenous and the regression results unbiased (Wooldridge 2009).

Table 2 displays the results of a DOLS estimation of our fully specified empirical model (Eq. (1)). The share of manufacturing in total number of employed persons (EMPMAN) represents the dependent variable. The estimated coefficient of the yen exchange rate (marked in bold) is negative as expected from theory and highly significant. Seen on the whole, also the other estimated coefficients are significant and their signs corresponding with our priors. TFP shows a negative coefficient, suggesting that higher productivity has resulted in a lower share of manufacturing employment, but this effect is not statistically significant. Gross domestic fixed capital formation shows a positive sign and is highly significant. As expected, manufacturing exports have a positive and significant effect on manufacturing employment, whereas outward direct investment has a negative and significant effect. Chinese exports show a positive sign, suggesting that the positive effects of Chinese economic development on Japanese manufacturing dominated the negative competition effect. Finally, the empirical realisations of the goodness-of-fit criteria, among them the very high R-Squared, indicate the appropriateness of our selected empirical model.

Our robustness checks reveal that the total goodness-of-fit does not become significantly lower if EXPCHIN is eliminated from our empirical model. This does not come

\footnotetext{
${ }^{8}$ The hysteresis argument is mainly related to the irreversibility of investment-type decisions, due to high fixed costs which cannot be recovered ex post (sunk costs). Industrial manufacturing production, the focus of the second part of this paper, is a very good example because it is dependent on investment-type decisions related to, among others, fixed investment, hiring and firing decisions and establishing distribution networks.
} 
Table 2 Dynamic least squares estimation for fully specified model

\begin{tabular}{|c|c|c|c|c|}
\hline \multicolumn{5}{|c|}{ Dependent Variable: EMPMAN } \\
\hline \multicolumn{5}{|c|}{ Method: Dynamic Least Squares (DOLS) } \\
\hline \multicolumn{5}{|c|}{ Sample (adjusted): 1973-2013 } \\
\hline \multicolumn{5}{|c|}{ Included observations: 41 after adjustments } \\
\hline \multicolumn{5}{|c|}{ Cointegrating equation deterministics: $\mathrm{C}$} \\
\hline \multicolumn{5}{|c|}{ Fixed leads and lags specification $($ lead $=1$, lag $=1)$} \\
\hline \multicolumn{5}{|c|}{ Long-run variance estimate (Bartlett kernel, Newey-West fixed bandwidth $=4.0000$ ) } \\
\hline Variable & Coefficient & Std. Error & t-Statistic & Prob. \\
\hline TFP & -10.49578 & 6.642659 & -1.580057 & 0.1337 \\
\hline CAP & 1.108099 & 0.135792 & 8.160269 & 0.0000 \\
\hline EXPCHIN & $2.20 \mathrm{E}-10$ & $8.54 \mathrm{E}-11$ & 2.572967 & 0.0204 \\
\hline EXPMAN & 1.42E-09 & 3.67E-10 & 3.879566 & 0.0013 \\
\hline OFDI & -0.000192 & $3.60 \mathrm{E}-05$ & -5.325351 & 0.0001 \\
\hline EXR & -0.051424 & 0.016242 & -3.166034 & 0.0060 \\
\hline $\mathrm{C}$ & 2.783452 & 5.976907 & 0.465701 & 0.6477 \\
\hline R-squared & 0.992483 & Mean dep & & 22.11307 \\
\hline Adjusted R-squared & 0.981208 & S.D. deper & & 3.295862 \\
\hline S.E. of regression & 0.451804 & Sum squar & & 3.266036 \\
\hline Long-run variance & 0.175494 & & & \\
\hline
\end{tabular}

Source: Compiled by authors

as a surprise since both variables represent indicators of the world business cycle, i.e., the so-called "global factor". For exactly this reason, we leave out EXPCHIN in our next DOLS-specification. The corresponding regression results are displayed in Table 3. Again, the estimation results clearly are in accordance with our priors.

As robustness checks we also conducted DOLS regressions with White correction of the coefficient covariance matrix (White 1980). There is no substantial change of the estimation results, with respect to the magnitude and the sign of the estimated coefficients. If at all, the significance of, for instance, the yen exchange rate, even slightly increases once again in the specification excluding Chinese exports. Moreover, we also enacted DOLS regression with Newey-West correction of the coefficient covariance matrix (Newey and West 1987). Again, the estimation results do not change much with respect to both the magnitude and the sign of the estimated coefficients. All these results are available on request.

Application of the DOLS procedure requires the time series to be non-stationary and to be cointegrated over time. We are able to show that both conditions are satisfied in our case. Evidence of non-stationarity has been delivered already by the results of our unit root tests in Section 3.1.2. And empirical support of cointegration among the variables contained in our empirical models is conveyed by cointegration tests (Table 4 for the fully specified model and Table 5 for the model without Chinese exports). Figures 4 and 5 display the residuals (which form the basis for the Engle-Granger cointegration tests described in Tables 4 and 5) and the actual and fitted values according to the DOLS regression models described in Tables 2 and 3, respectively. 
Table 3 Dynamic least squares estimation for model excluding Chinese exports

Dependent Variable: EMPMAN

Method: Dynamic Least Squares (DOLS)

Sample (adjusted): 1973-2013

Included observations: 41 after adjustments

Cointegrating equation deterministics: $\mathrm{C}$

Fixed leads and lags specification $($ lead $=1$, lag $=1)$

Long-run variance estimate (Bartlett kernel, Newey-West fixed bandwidth $=4.0000$ )

\begin{tabular}{|c|c|c|c|c|}
\hline Variable & Coefficient & Std. Error & t-Statistic & Prob. \\
\hline TFP & -4.949611 & 8.354137 & -0.592474 & 0.5602 \\
\hline CAP & 0.930860 & 0.140335 & 6.633109 & 0.0000 \\
\hline EXPMAN & 1.10E-09 & $4.76 \mathrm{E}-10$ & 2.309287 & 0.0317 \\
\hline OFDI & -0.000122 & $3.54 \mathrm{E}-05$ & -3.440251 & 0.0026 \\
\hline EXR & -0.055554 & 0.020831 & -2.666873 & 0.0148 \\
\hline $\mathrm{C}$ & 3.580114 & 8.186393 & 0.437325 & 0.6666 \\
\hline R-squared & 0.988524 & \multicolumn{2}{|c|}{ Mean dependent var } & 22.11307 \\
\hline Adjusted R-squared & 0.977048 & \multicolumn{2}{|c|}{ S.D. dependent var } & 3.295862 \\
\hline S.E. of regression & 0.499324 & \multicolumn{2}{|c|}{ Sum squared resid } & 4.986488 \\
\hline Long-run variance & 0.337452 & & & \\
\hline
\end{tabular}

Source: Compiled by authors

Table 4 Test for cointegration (for fully specified DOLS model)

Cointegration Test - Engle-Granger

Equation: EQ01

Specification: EMPMAN TFP CAP EXPCHIN EXPMAN OFDI EXR C

Cointegrating equation deterministics: $\mathrm{C}$

Null hypothesis: Series are not cointegrated

Dependent Variable: D(RESID)

Method: Least Squares

Sample (adjusted): 1972-2014

Included observations: 43 after adjustments

Variable

$\operatorname{RESID}(-1)$

R-squared

$-0.282619$

Adjusted R-squared

0.141977

S.E. of regression

0.141977

0.518638

Sum squared resid

11.29738

Log likelihood

$-32.27683$

Durbin-Watson stat

1.855124
Std. Error

$\mathrm{t}-$ Statistic

Prob.

$0.107162 \quad-2.637302$

0.0117

Mean dependent var

0.005944

S.D. dependent var

0.559905

Akaike info criterion

1.547760

Schwarz criterion

1.588718

Hannan-Quinn criterion

Source: Compiled by authors

\section{iㅡㄹ Springer}


Table 5 Test for cointegration (for DOLS model without Chinese exports)

Cointegration Test - Engle-Granger

Equation: EQ01

Specification: EMPMAN TFP CAP EXPMAN OFDI EXR C

Cointegrating equation deterministics: $\mathrm{C}$

Null hypothesis: Series are not cointegrated

Engle-Granger Test Equation:

Dependent Variable: D(RESID)

Method: Least Squares

Sample (adjusted): 1972-2014

Included observations: 43 after adjustments

\begin{tabular}{|c|c|c|c|c|}
\hline Variable & Coefficient & Std. Error & t-Statistic & Prob. \\
\hline $\operatorname{RESID}(-1)$ & -0.367846 & 0.119751 & -3.071757 & 0.0037 \\
\hline R-squared & 0.183441 & \multicolumn{2}{|c|}{ Mean dependent var } & -0.001782 \\
\hline Adjusted R-squared & 0.183441 & \multicolumn{2}{|c|}{ S.D. dependent var } & 0.677695 \\
\hline S.E. of regression & 0.612390 & \multicolumn{2}{|c|}{ Akaike info criterion } & 1.880087 \\
\hline Sum squared resid & 15.75091 & \multicolumn{2}{|c|}{ Schwarz criterion } & 1.921045 \\
\hline Log likelihood & -39.42186 & \multicolumn{2}{|c|}{ Hannan-Quinn criterion } & 1.895191 \\
\hline Durbin-Watson stat & 1.861195 & & & \\
\hline
\end{tabular}

Source: Compiled by authors

It turns out that the residuals in Figs. 4 and 5 are well-behaved, i.e., stationary, and that the Engle-Granger tests do in fact reject the null hypothesis of no cointegration.

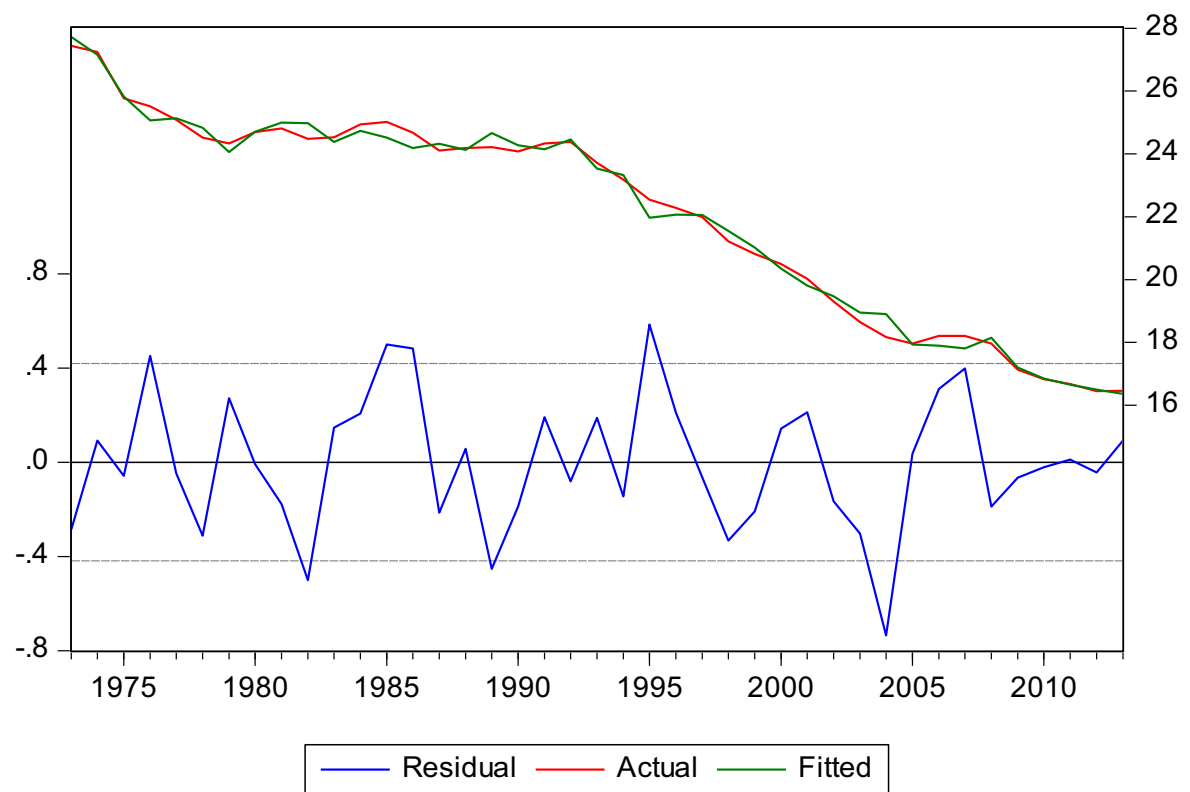

Source: Compiled by authors.

Fig. 4 Residuals, actual and fitted values (fully specified DOLS model) 


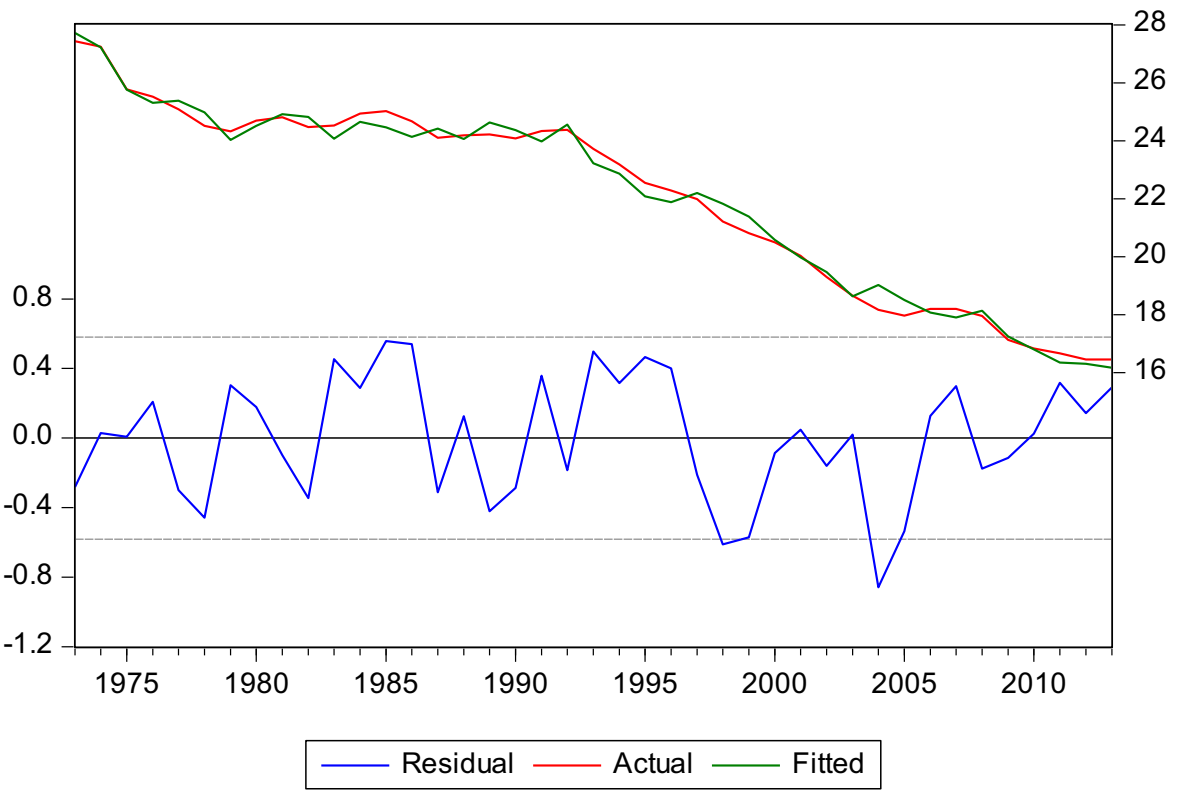

Source: Compiled by authors.

Fig. 5 Residuals, actual and fitted values (DOLS model excluding Chinese exports)

Seen on the whole, thus, we feel legitimised to argue that the yen real effective exchange rate has had a long-run negative impact on the share of manufacturing in total number of employed persons in Japan since the 1970s.

We now turn to the second option mentioned above, that is to conduct ARDL estimations based on the first differences of the non-stationary variables.

\subsubsection{Autoregressive Distributed Lag (ARDL) Estimations: In Search of the Dynamics Underlying "Hollowing Out"}

In this section, we employ ARDL estimations in order to estimate the intertemporal dynamics of the equation explaining the change in manufacturing employment (D(EMPMAN)). ARDLs are standard least squares regressions that include lags of both the dependent variable and explanatory variables as regressors (Greene 2008). Their application requires the data to be stationary. This leads us to employ (only) the first differences of the variables of our empirical model. This comes at the cost that we are not able to exploit level information (as it is the case in our cointegration exercise). The ARDL model selection process employed by us uses the same sample for each estimation and selects the final model by maximising the empirical realisation of information criteria (in our case, of the Akaike criterion). The empirical results of the ARDL exercise are displayed in Table 6.

The expression $\operatorname{ARDL}(1,2,0,1,1,0,0)$ in Table 6 indicates the model selected by our search algorithm according to the Akaike information criterion. The first entry in brackets denotes the lags of the endogenous lagged variable. The second entry corresponds with the lag number of the change of total factor productivity, the third entry 
Table 6 ARDL estimation of fully specified model

Dependent Variable: D(EMPMAN)

Method: ARDL

Sample (adjusted): 1973-2014

Included observations: 42 after adjustments

Maximum dependent lags: 2 (Automatic selection)

Model selection method: Akaike info criterion (AIC)

Dynamic regressors (2 lags, automatic): D(TFP) D(CAP) D(EXPMAN) D(EXPCHIN) D(OFDI) D(EXR)

Fixed regressors: $\mathrm{C}$

Number of models evaluated: 1458

Selected Model: ARDL(1, 2, 0, 1, 1, 0,0)

\begin{tabular}{|c|c|c|c|c|}
\hline Variable & Coefficient & Std. Error & t-Statistic & Prob.* \\
\hline D(EMPMAN(-1)) & 0.391195 & 0.141019 & 2.774061 & 0.0094 \\
\hline $\mathrm{D}(\mathrm{TFP})$ & -3.808531 & 4.248908 & -0.896355 & 0.3772 \\
\hline $\mathrm{D}(\mathrm{TFP}(-1))$ & 2.768530 & 3.802030 & 0.728171 & 0.4722 \\
\hline $\mathrm{D}(\mathrm{TFP}(-2))$ & -6.491839 & 3.288327 & -1.974207 & 0.0576 \\
\hline $\mathrm{D}(\mathrm{CAP})$ & 0.109411 & 0.071213 & 1.536395 & 0.1349 \\
\hline D(EXPMAN) & $4.35 \mathrm{E}-10$ & $1.70 \mathrm{E}-10$ & 2.564722 & 0.0156 \\
\hline D(EXPMAN(-1)) & $-2.45 \mathrm{E}-10$ & $1.18 \mathrm{E}-10$ & -2.081662 & 0.0460 \\
\hline D(EXPCHIN) & $-1.47 \mathrm{E}-10$ & $1.01 \mathrm{E}-10$ & -1.456282 & 0.1557 \\
\hline D(EXPCHIN(-1)) & $1.50 \mathrm{E}-10$ & 8.89E-11 & 1.683592 & 0.1026 \\
\hline $\mathrm{D}(\mathrm{OFDI})$ & $2.83 \mathrm{E}-07$ & $5.12 \mathrm{E}-06$ & 0.055276 & 0.9563 \\
\hline $\mathrm{D}(\mathrm{EXR})$ & -0.016393 & 0.006865 & -2.387858 & 0.0234 \\
\hline $\mathrm{C}$ & -0.175573 & 0.068215 & -2.573808 & 0.0152 \\
\hline R-squared & 0.486519 & \multicolumn{2}{|c|}{ Mean dependent var } & -0.266650 \\
\hline Adjusted R-squared & 0.298243 & \multicolumn{2}{|c|}{ S.D. dependent var } & 0.362367 \\
\hline S.E. of regression & 0.303559 & \multicolumn{2}{|c|}{ Akaike info criterion } & 0.688472 \\
\hline Sum squared resid & 2.764433 & \multicolumn{2}{|c|}{ Schwarz criterion } & 1.184949 \\
\hline Log likelihood & -2.457906 & \multicolumn{2}{|c|}{ Hannan-Quinn criterion } & 0.870450 \\
\hline F-statistic & 2.584071 & \multicolumn{2}{|c|}{ Durbin-Watson stat } & 1.718422 \\
\hline Prob(F-statistic) & 0.019257 & & & \\
\hline
\end{tabular}

Source: Compiled by authors

indicates the lag number of the change in gross domestic fixed capital formation (CAP). The fourth one stands for the lag number of the change in manufacturing exports (EXPMAN). The fifth entry denotes the lag number of the change in Chinese exports (EXPCHIN). The sixth entry is related to the lag number of the outward direct investment variable (OFDI). And the seventh entry refers to the lag number of lags of the yen exchange rate (EXR). The result column containing the yen exchange rate effect denotes the significant estimated coefficient for the exchange rate $(-0.016393)$ and its significance level (0.02) in the selected ARDL model. Values in brackets in Table 6 denote the respective significance level (probabilities). Once again, we find a positive and significant effect of the yen exchange rate on the share of manufacturing employment. 
Summing up, our annual data analysis based on DOLS and ARDL estimations provides robust results which indicate that increases in the real effective yen exchange rate, i.e., appreciations, did have significant negative effects on the share of manufacturing in total employment in Japan. This is despite the fact that the yen also experiences longer periods of real effective depreciation and is thus indicative of hysteresis effects (Krugman and Baldwin 1987; Belke et al. 2013). Our DOLS estimations also find a negative and significant effect of outward FDI.

\subsection{Analysis with Monthly Data, 1991-2017}

Having investigated the long-term impact of real effective exchange movements on aggregate manufacturing employment with annual data spanning almost five decades, we now turn to an analysis using higher frequency and, importantly, sector specific data. If exchange rate changes are to have a long-term impact on manufacturing, there ought to be some short-term impacts too. Using sector-specific data at higher frequency allows us to uncover such potential effects. Ideally, we would be using sector-specific employment to mirror the annual data analysis. However, since we were not able to obtain matching monthly sector-specific employment data, we chose to use sectorspecific industrial production data as dependent variable as a second-best option, given that industrial production and industrial employment are highly correlated.

\subsubsection{Data and Empirical Model}

In order to exploit our new dataset on sector-specific yen exchange rates (Fig. 6), which are calculated by using industry-specific producer price indices (RIETI 2018), we now estimate the real yen effective exchange rate effects on Japanese industrial production, using monthly data from 1991 to 2017 :

$$
\begin{aligned}
I N P \perp= & \beta_{0}+\beta_{1} I N P X_{t-1}+\beta_{2} E X \_+\beta_{3} \text { REER } X+\beta_{4} \text { INDINPUTPRICE } \\
& +\beta_{5} \text { TFP }+\beta_{6} \text { INPUSA }+\varepsilon,
\end{aligned}
$$

where $I N P \_X=$ Industrial production by industry $X, E X \_X=$ Exports by industry $X$, REER_X $X=$ Industry-specific real effective exchange rate of industry $X$ for 11 different industrial sectors and manufacturing as a whole, INDINPUTPRICE = Industrial input price, and INPUSA = Industrial production United States. ${ }^{9}$ Appendix Table 15 provides further details on the variables and sources used.

Our data set covers the following 11 industrial sectors: chemicals (CHEMICALS), electrical equipment (ELECTRICALEQUIPMENT), food (FOOD), general machinery (GENERALMACHINERY), optical instruments (OPTICALINSTRUMENTS), paper (PAPER), petroleum related products (PETROLEUM), rubber related products (RUBBER), textiles (TEXTILES), transport equipment (TRANSPORTEQUIPMENT), wood related products (WOOD) and manufacturing as a whole (MANUFACTURINGALL). Details of these sectors are provided in Appendix Table 16.

\footnotetext{
${ }^{9}$ The time series of industrial production have been seasonally adjusted, using the Census X-13 procedure.
} 


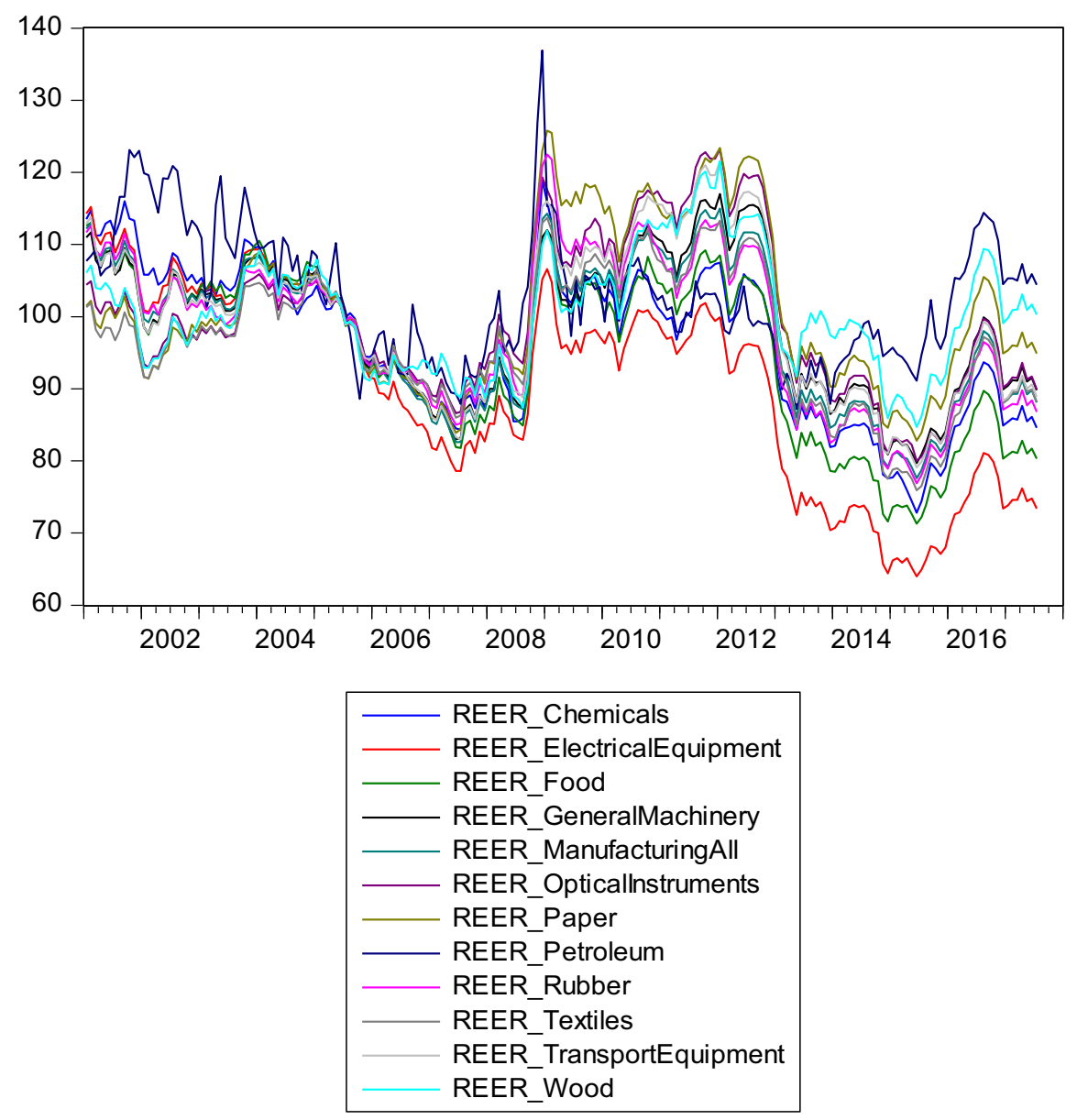

Source: Compiled by authors with data from RIETI (2018).

Note: "ManufacturingAll" refers to the average REER of the various industrial sectors.

Fig. 6 Real effective exchange rates for different industrial sectors

While all other variables are industry-specific, INDINPUTPRICE and INPUSA are non-industry-specific variables. In this sense, we follow a mixed panel-time series modelling approach after having estimated sector-specific ARDL models. Figure 7 shows industrial production (INP) and industry-specific real effective exchange rates (REER) for selected industries. The two series tend to move in opposite direction, indicating that real effective exchange rates may indeed have a negative impact on industrial production.

\subsubsection{Unit Root Tests}

We now proceed with unit root tests of the variables listed below Eq. (2) to be employed in our ARDL estimations and in our empirical mixed time series-panel 


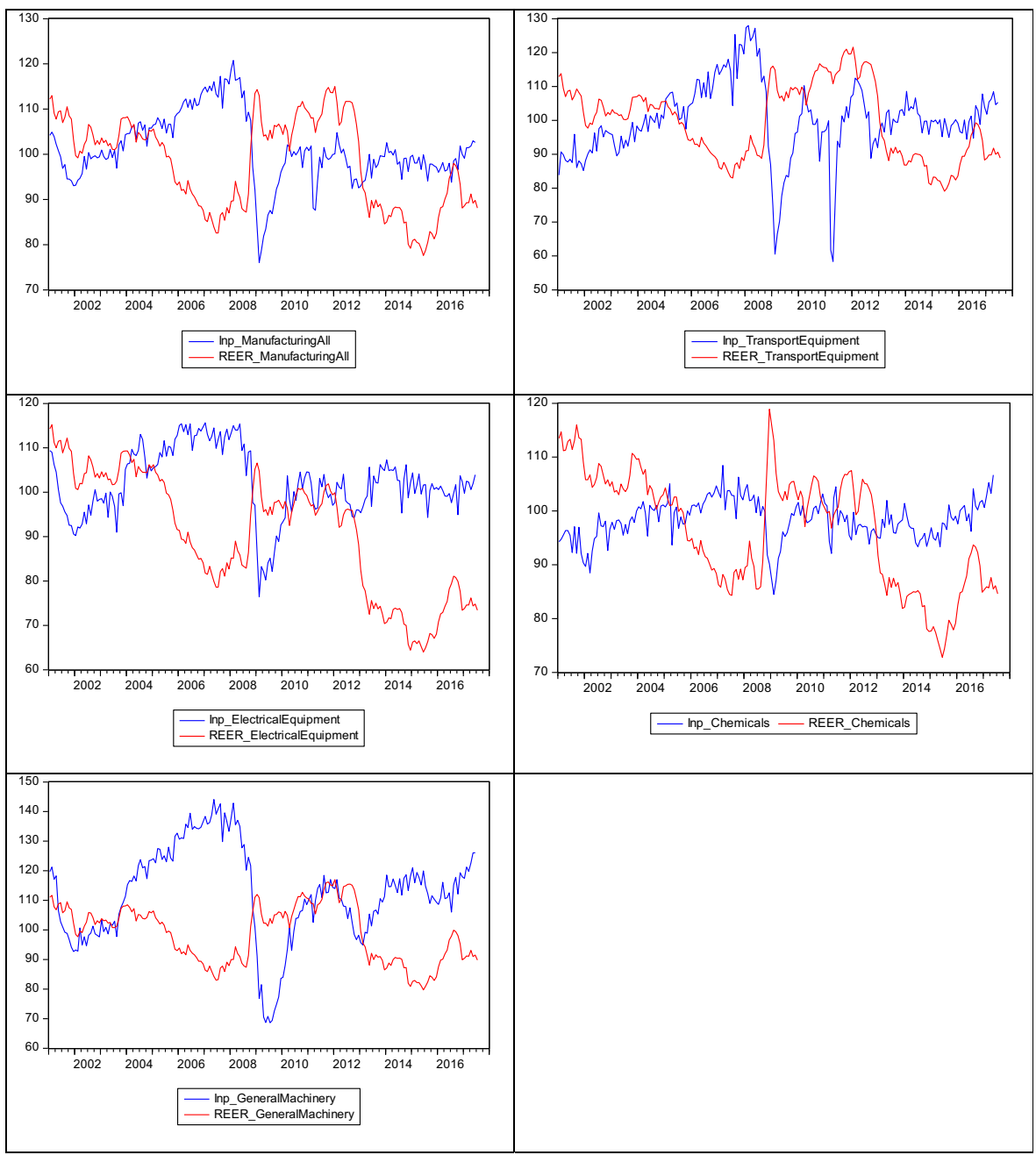

Source: Compiled by authors with data from RIETI (2018) and METI (2017).

Fig. 7 Industrial production and industry-specific real effective exchange rates for selected industries

models of Japanese industrial production which both necessitate the variables to be stationary.

The wide array of unit root tests we conducted, including the ordinary Augmented-Dickey-Fuller test, the Dickey-Fuller GLS (ERS) test, the PhillipsPerron test, the Kwiatowski-Phillips-Schmidt-Shin test and the Ng-Perron unit root test, suggest an I(1) process for each of the variables. Hence, we proceed with the individual variables considering them as I(1) variables which have to be differenced once in order to become stationary. The results are available on request.

We first conduct sector-specific Autoregressive Distributed Lag (ARDL) estimations based on first differences of the (non-pooled) variables. 


\subsubsection{Sector-Specific Autoregressive Distributed Lag-Estimations for Japanese Industrial Production}

The pattern of the results of our ARDL estimations of Eq. (2) based on first differences of the (non-pooled) sector-specific and two further non-sector specific variables is displayed in Table 7. We rely on the same mechanics of ARDL model selection which have already been explained in Section 3.1.4. This time, entries in the "selected model" column indicate the model selected according the Akaike information criterion. The first entry in brackets denotes the lags of the endogenous lagged variable, the second entry corresponds with the lag number of the change of the sector-specific exchange rate, the third entry indicates the lag number of the change in US industrial production and the fourth stands for the lag number of the change in Japanese industrial input prices. Deviating from the specification of Eq. (2) we leave out sector-specific exports for reasons explained above. Column 2 in Table 7 containing the yen exchange rate effect denotes the significant estimated coefficients for the yen exchange rate in the selected ARDL model. The total exchange rate effect (next column) is indicated in the third column of Table 7 by the sum of the period-specific significant entries. Values in brackets denote the respective significance level (probabilities). To illustrate, Table 8 contains a detailed ARDL estimation example for manufacturing sector as a whole. Its results are summarised in the first row of Table 7. Here, the impact coefficient of the exchange rate on the industrial production in the Japanese manufacturing sector is -0.61 with a high significance of below 0.01 .

The ordinary Pearson correlations conducted for the example of the Japanese manufacturing sector displayed in Table 9 demonstrate that exports of the Japanese manufacturing sector dominate any impact on the industrial production of the

Table 7 Impact of the real effective yen exchange rate on Japanese industrial production - A survey of estimated sector-specific ARDL models (excluding exports)

\begin{tabular}{|c|c|c|c|}
\hline Japanese industry sector & Selected ARDL model & Yen exchange rate effects & Yen exchange rate effect (total) \\
\hline Manufacturing all & $\operatorname{ARDL}(4,3,2,0)$ & Lag 3: $-0.61(0.0032)$ & -0.61 \\
\hline Chemicals & $\operatorname{ARDL}(2,3,1,0)$ & Lag 3: $-0.41(0.0036)$ & -0.41 \\
\hline Electrical equipment & $\operatorname{ARDL}(3,3,1,2)$ & Lag 3: -1.04 (0.0101) & -1.04 \\
\hline Transport equipment & $\operatorname{ARDL}(3,3,2,0)$ & Lag 3: $-0.83(0.0148)$ & -0.83 \\
\hline Rubber & $\operatorname{ARDL}(3,3,1,0)$ & $\begin{array}{l}\text { Lag 1: } 0.44(0.0981) \\
\text { Lag 3: }-0.95(0.0004)\end{array}$ & -0.51 \\
\hline Optical instruments & $\operatorname{ARDL}(2,3,0,0)$ & $\begin{array}{l}\text { Lag 0: } 0.90(0.0294) \\
\text { Lag 3: } 1.43(0.0004)\end{array}$ & -0.53 \\
\hline Paper & $\operatorname{ARDL}(4,3,1,0)$ & Lag 3: $-0.38(0.0008)$ & -0.38 \\
\hline Food & $\operatorname{ARDL}(3,0,0,0)$ & - & - \\
\hline Textiles & $\operatorname{ARDL}(4,3,4,0)$ & $\begin{array}{l}1: 0.27(0.0785) \\
3:-0.25(0.0830)\end{array}$ & 0.01 \\
\hline
\end{tabular}


Table 8 Impact of the real effective yen exchange rate on Japanese manufacturing industrial production - an estimated ARDL model

Dependent Variable: D(INP_MANUFACTURINGALL)

Method: ARDL

Sample (adjusted): 2001 M06-2017 M06

Included observations: 193 after adjustments

Maximum dependent lags: 4 (Automatic selection)

Model selection method: Akaike info criterion (AIC)

Dynamic regressors (4 lags, automatic): D(REER_MANUFACTURINGALL) D(INPUSA) D(INDINPUTPRICE)

Fixed regressors: $\mathrm{C}$

Number of models evaluated: 500

Selected Model: $\operatorname{ARDL}(4,3,2,0)$

\begin{tabular}{lllll} 
Variable & Coefficient & Std. Error & t-Statistic & Prob.* \\
D(INP_MANUFACTURINGALL(-1)) & -0.697699 & 0.072846 & -9.577785 & 0.0000 \\
D(INP_MANUFACTURINGALL(-2)) & -0.867266 & 0.086039 & -10.07993 & 0.0000 \\
D(INP_MANUFACTURINGALL(-3)) & -0.283453 & 0.087358 & -3.244752 & 0.0014 \\
D(INP_MANUFACTURINGALL(-4)) & -0.165924 & 0.071672 & -2.315035 & 0.0217 \\
D(REER_MANUFACTURINGALL) & 0.189543 & 0.219093 & 0.865127 & 0.3881 \\
D(REER_MANUFACTURINGALL(-1)) & 0.213997 & 0.216040 & 0.990543 & 0.3232 \\
D(REER_MANUFACTURINGALL(-2)) & 0.040311 & 0.213098 & 0.189164 & 0.8502 \\
D(REER_MANUFACTURINGALL(-3)) & -0.614792 & 0.205586 & -2.990434 & 0.0032 \\
D(INPUSA) & 0.892882 & 0.661064 & 1.350675 & 0.1785 \\
D(INPUSA(-1)) & 2.602084 & 0.653861 & 3.979568 & 0.0001 \\
D(INPUSA(-2)) & 0.966521 & 0.681389 & 1.418456 & 0.1578 \\
D(INDINPUTPRICE) & -0.013329 & 0.085517 & -0.155863 & 0.8763 \\
C & -0.227603 & 0.422910 & -0.538183 & 0.5911 \\
R-squared & 0.549736 & Mean dependent var & 0.050777 \\
Adjusted R-squared & 0.519718 & S.D. dependent var & 8.436238 \\
S.E. of regression & 5.846512 & Akaike info criterion & 6.434549 \\
Sum squared resid & 6152.707 & Schwarz criterion & 6.654316 \\
Log likelihood & -607.9340 & Hannan-Quinn criterion & 6.523548 \\
F-statistic & 18.31378 & Durbin-Watson stat & 2.104685 \\
Prob(F-statistic) & 0.000000 & & \\
\hline
\end{tabular}

Source: Compiled by authors

same sector. Our additional robustness checks show that we can generalise this statement for all sectors considered here: branch-specific exports dominate any impact on the respective sector's industrial production.

As a robustness check, we estimated sector-specific ARDL models, this time including Japanese exports. The results are surveyed in Table 10. The pattern of the results does change in the sense that only for chemicals, electrical equipment, rubber, paper and food there is still a significant impact of the sector-specific yen exchange rate with the "correct" sign. 


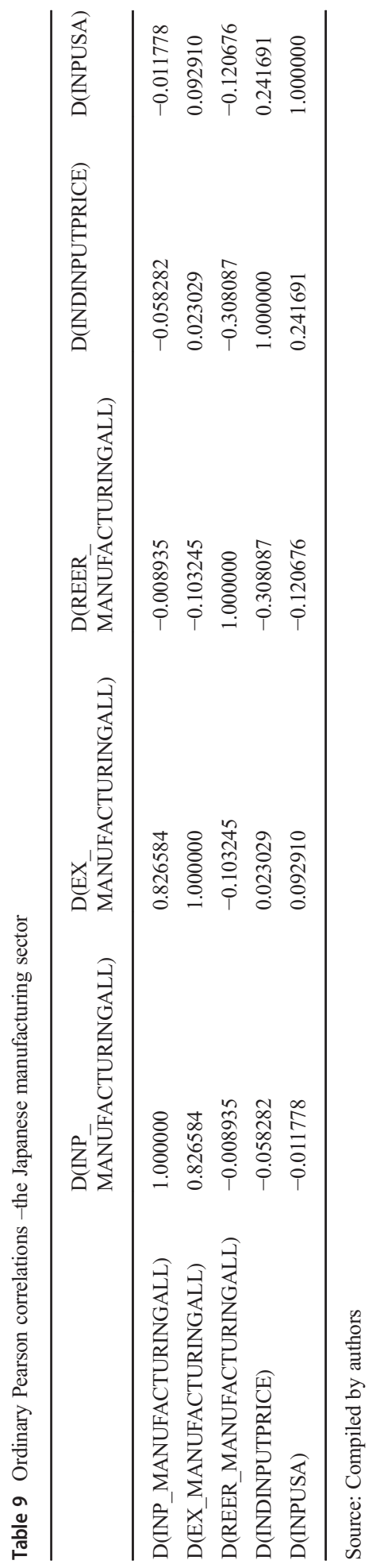


Table 10 Impact of the real effective yen exchange rate on Japanese industrial production - a survey of estimated sector-specific ARDL models (including exports)

\begin{tabular}{|c|c|c|c|}
\hline Japanese industry sector & Selected ARDL model & Yen exchange rate effects & Yen exchange rate effect (total) \\
\hline \multirow[t]{4}{*}{ Manufacturing all } & \multirow[t]{4}{*}{$\operatorname{ARDL}(4,3,4,1,0)$} & Lag 0: $0.49(0.0001)$ & \multirow[t]{4}{*}{0.78} \\
\hline & & Lag 1: 0.30 (0.0198) & \\
\hline & & Lag 2: $0.26(0.0377)$ & \\
\hline & & Lag 4: $-0.27(0.0183)$ & \\
\hline Chemicals & $\operatorname{ARDL}(2,0,3,0,1)$ & Lag 3: $-0.40(0.0020)$ & -0.40 \\
\hline \multirow[t]{2}{*}{ Electrical equipment } & \multirow[t]{2}{*}{$\operatorname{ARDL}(3,4,4,2,4)$} & Lag 3: $-0.74(0.0180)$ & \multirow[t]{2}{*}{-1.31} \\
\hline & & Lag 4: -0.57 (0.0604) & \\
\hline Transport equipment & $\operatorname{ARDL}(3,2,0,0,1)$ & Lag 0: 0.67 (0.0004) & 0.67 \\
\hline \multirow[t]{2}{*}{ Rubber } & \multirow[t]{2}{*}{$\operatorname{ARDL}(4,1,3,0,1)$} & Lag 1: $0.53(0.0268)$ & \multirow[t]{2}{*}{-0.31} \\
\hline & & Lag 3: -0.84 (0.0004) & \\
\hline \multirow[t]{3}{*}{ Optical instruments } & \multirow[t]{3}{*}{$\operatorname{ARDL}(4,6,3,0,2)$} & Lag 0: $1.30(0.0008)$ & \multirow[t]{3}{*}{1.27} \\
\hline & & Lag 1: $0.80(0.0382)$ & \\
\hline & & Lag 3: $-0.83(0.0276)$ & \\
\hline Paper & $\operatorname{ARDL}(4,4,3,3,2)$ & Lag 3: $-0.26(0.0101)$ & -0.26 \\
\hline Food & $\operatorname{ARDL}(3,4,3,0,0)$ & Lag 3: -0.67 & -0.67 \\
\hline Textiles & $\operatorname{ARDL}(4,4,0,3,3)$ & - & - \\
\hline
\end{tabular}

Source: Compiled by authors

\subsubsection{Panel Estimations}

As a first step, we test for unit roots in the pooled sector-specific time series. In order to make sure that we employ stationary variables in our panel estimations we conducted the following panel unit root tests for the pools of sector-specific variables: Levin, Lin and Chu (Levin et al. 2002), Breitung (2000), Im, Pesaran and Shin (Im et al. 2003), Fisher-type tests using ADF and PP tests (Maddala and Wu 1999; Choi 2001), and Hadri (2000). All variables turned out to be I(1). The results are available on request.

As a second step, we conduct Pooled Least Squares estimations of a mixed time series-cross section model based on stationary time series with White crosssection standard errors (to allow for general contemporaneous correlation between the branch-specific residuals) and White covariance (White 1980; MacKinnon and White 1985). Non-zero covariances are allowed across cross-sections (degree-offreedom corrected). The estimator we employ in this study is thus robust to crossequation (contemporaneous) correlation between the branch-specific residuals and heteroskedasticity. The estimation results for our final model are displayed in Table 11.

As a third step, we conduct Pooled Estimated Generalised Least Squares (EGLS, cross-section weights), once again with White cross-section standard errors and White covariance. The results are summarised in Table 12. The results 


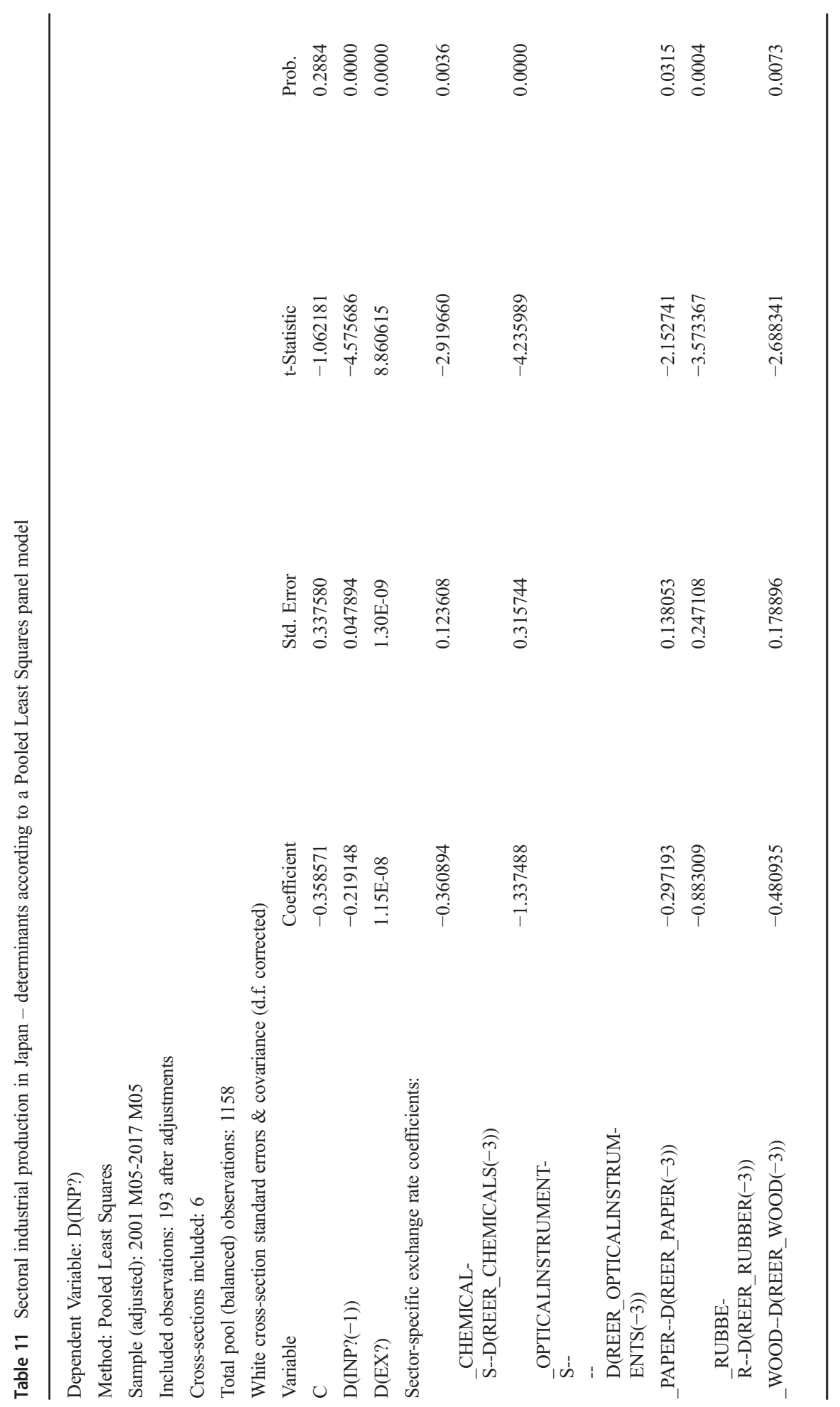




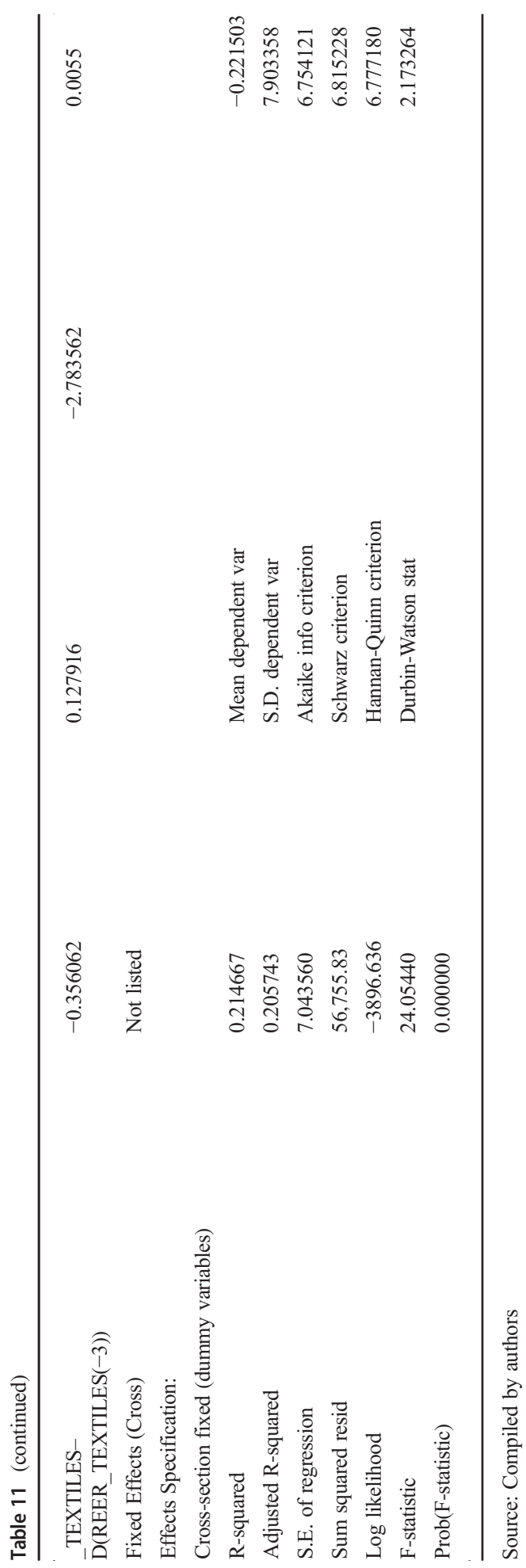

Springer 


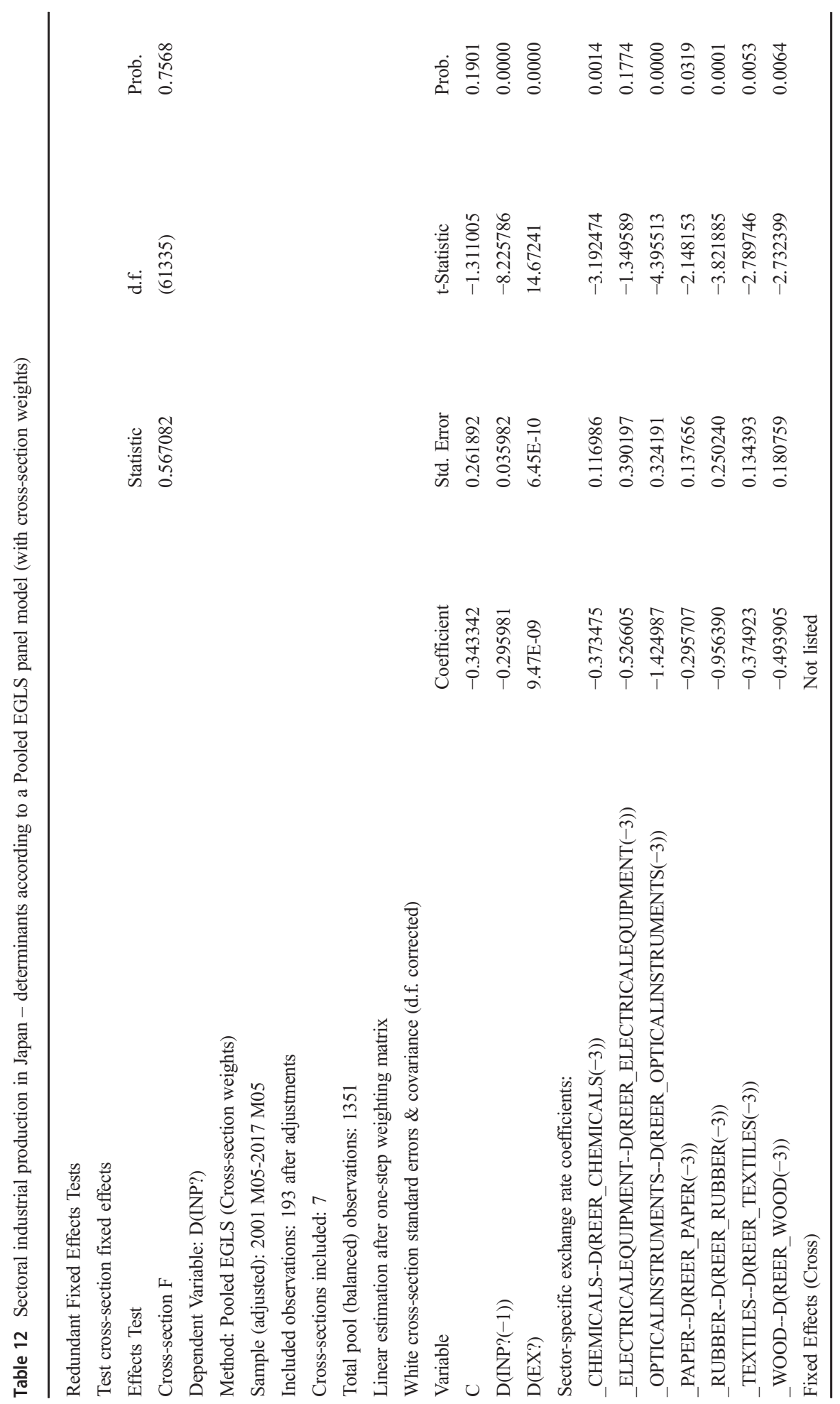


Belke A., Volz U.

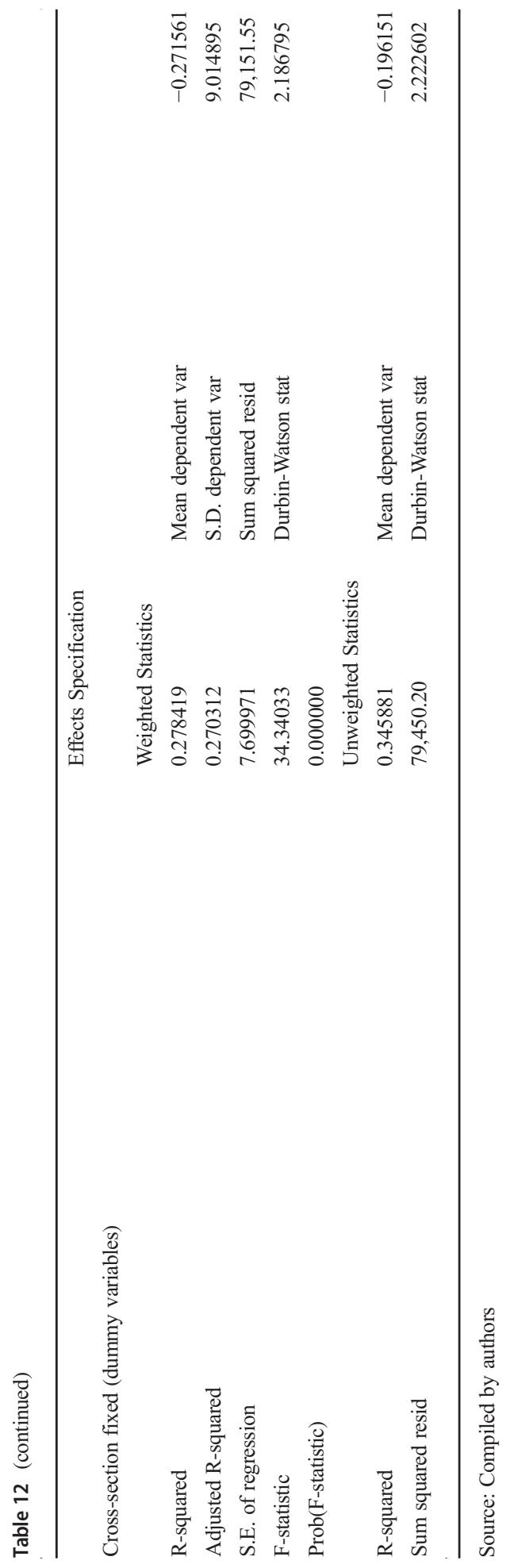

昞 Springer 
of our fixed effects redundancy test (at the beginning of Table 12) support our specific choice of fixed effects empirically.

And as a fourth and final step, we present estimation results based on Pooled Estimated Generalised Least Squares (EGLS) regressions conducted by the crosssection Seemingly Unrelated Regression (SUR) method (Table 13). ${ }^{10}$ Also in this case, we rely on White cross-section standard errors and White covariance. Again, the tabulated results of the fixed effects redundancy test (in the upper part of Table 13) empirically corroborate our specific choice of fixed effects. In all three estimation variants applied here we allow not only for fixed effects in the constant but also for cross-section specific slope coefficients. The selection of the final model was conducted according to the same criteria applied throughout the article and described in detail beforehand.

Overall, the estimation results displayed in Tables 11, 12 and 13 again appear wellbehaved with an eye on our main hypothesis. Significant negative sector-specific impacts of the yen effective real exchange rate can be established for at least six and a maximum of all nine sectors, the exact number of sectors depending on the chosen estimation procedure. This corroborates the empirical findings of Sato et al. (2013) and Thorbecke (2012) for Japanese exports.

According to our Pooled Least Squares estimations (Table 11) significantly negative effects of the (sector-specific) yen exchange rate on Japanese industrial production emerge for the chemicals, the optical instruments, the paper, the rubber, the wood and the textiles sectors.

Our estimations based on Pooled EGLS (cross-section weights, Table 12) reveal that the (sector-specific) yen exchange rate negatively impacts sectoral industrial production in the chemicals, the optical instruments, the paper, the rubber, the textiles and the wood sectors.

The expected negative sectoral exchange rate effect emerges from our Pooled EGLS (Cross-section SUR) estimates for the chemicals, the optical instruments, the rubber, the textiles, the transport equipment and the wood sectors (Table 13). We would like to stress that the evidence of negative yen exchange rate impacts on Japanese sectoral industrial production is thus confirmed by the most sophisticated estimation method applied by us in this article: the feasible GLS specification correcting for both cross-section heteroskedasticity and contemporaneous correlation (cross-section SUR).

Thus, for five industrial sectors (chemicals, optical instruments, rubber, wood and textiles) all three models find negative and significant coefficient estimates for the yen exchange rate, while such effects are found for a further sector (paper) in two out of the three estimated estimation methods (Pooled Least Squares and Pooled EGLS/Cross-section SUR). Furthermore, Pooled EGLS finds significant negative effect also for the transport equipment sector. In all cases, the sectoral yen exchange rate enters the final model consistently with a lag of three months (time-to-build effect). What is more, the selected empirical models are rather parsimonious in terms of the number of variables included. The (changes in the)

\footnotetext{
${ }^{10}$ Cross-section SUR allows for contemporaneous correlation between cross-sections (clustering by period). It is sometimes referred to as the Parks estimator.
} 


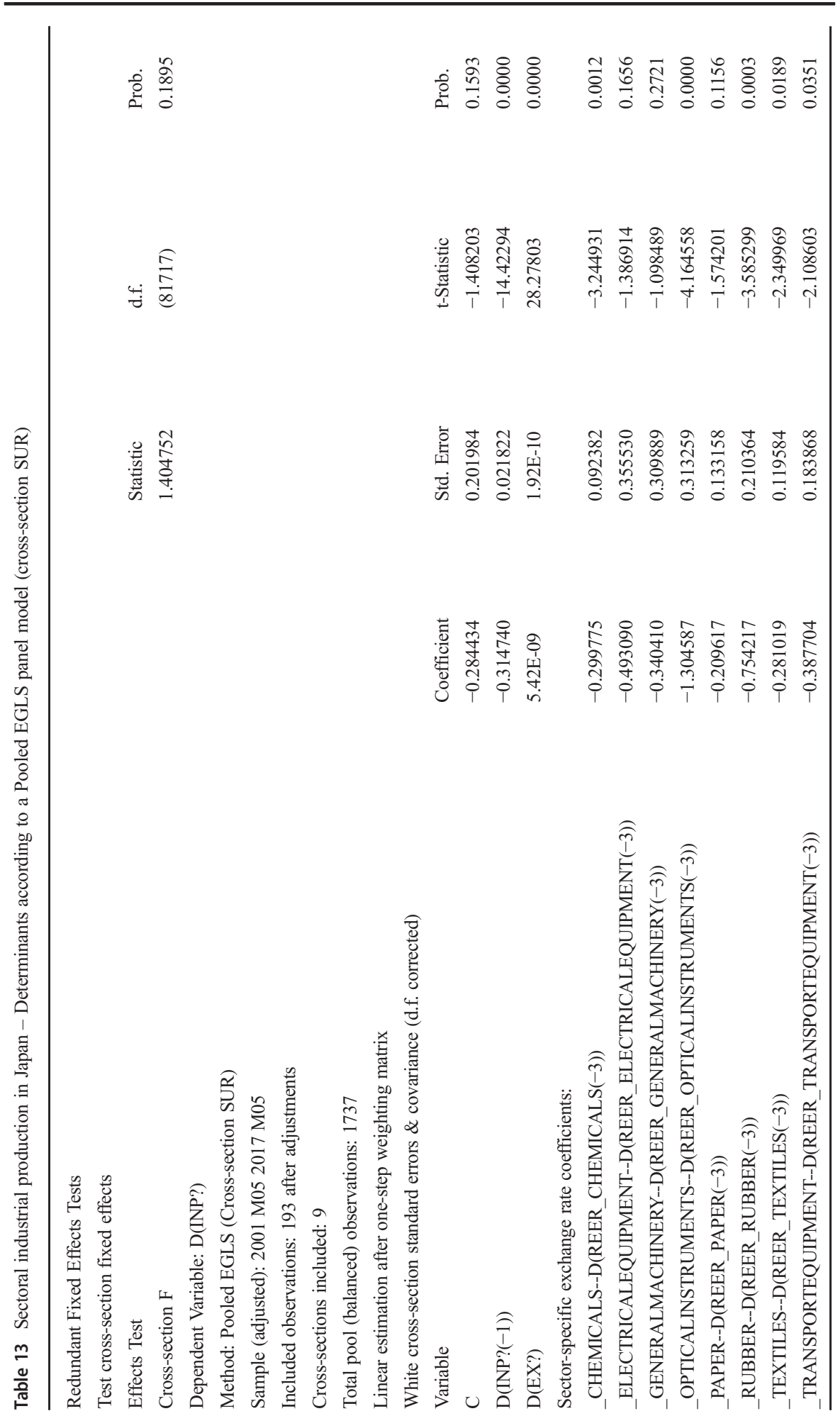




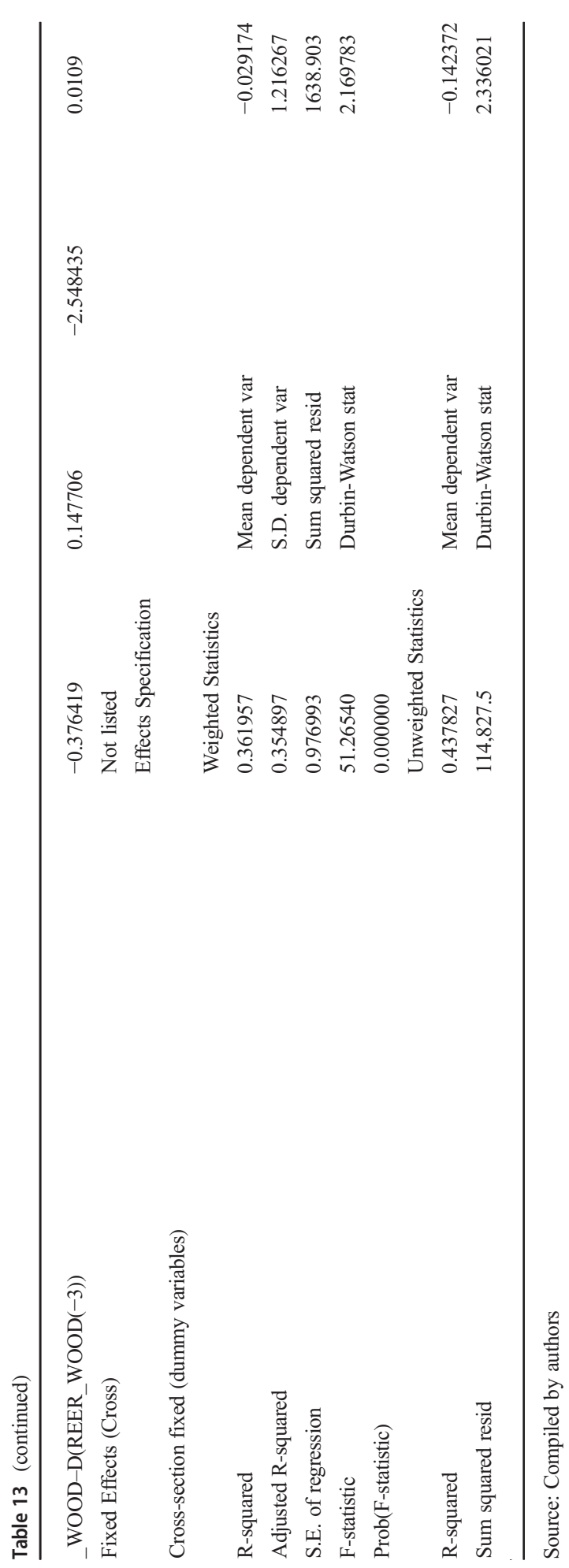


Japanese industrial input price (INDINPUTPRICE) and US industrial production (INPUSA) are not part of the finally selected model. However, the lagged endogenous variable (change in Japanese industrial production) turns out to be highly significant throughout. Hence, in accordance with, for instance, Belke and Gros (2001), we feel legitimised to argue that our final empirical models can be interpreted as (at least partly) reduced forms against which we are able to separate the additional marginal impacts of the yen exchange rate and Japanese exports on industrial production. ${ }^{11}$ Finally, critics may argue that the empirical realisations of the R-squared are not overly high. However, this type of evidence is quite typical of regressions of changes on changes. Moreover, the R-squared in our estimations appears to be located in the upper possible range.

Summing up, in our monthly data analysis with sector-specific data, both ARDL estimations and estimations of a mixed time series-cross section model suggest small but highly significant effects of the real yen effective exchange rate (REER) on industrial production for a broad range of industrial sectors. ${ }^{12}$

\section{Conclusions}

In this article we have investigated the role of the yen exchange rate in the deindustrialisation that has taken place in Japan over recent decades. There are certainly multiple factors that have played a role in this process, and we do not seek to evoke the impression that the exchange rate has been the single most important factor. Yet our results suggest that a strong yen had more than just transitory effects on Japanese manufacturing employment and output.

In our annual data analysis, the DOLS and ARDL estimations provide robust results which indicate that appreciations of the real effective yen exchange rate did have significant negative effects on the share of manufacturing in total employment in Japan. This is despite the fact that the yen also experienced longer periods of real effective depreciation, which is indicative of hysteresis effects on manufacturing. Our findings are consistent with recent research on the hollowing out of the U.S. economy, where findings by Campbell (2017) also point at the presence of hysteresis effects. But we should also highlight that the magnitude of the exchange rate effects in our annual data analysis are much smaller than of those variables that have the biggest effect on manufacturing employment, namely TFP and fixed capital formation.

We also find significant negative effects of the real effective yen exchange rate on industrial output when using monthly and industry-specific data. Our ARDL estimations find significant negative effects for chemicals, electrical equipment, transport

\footnotetext{
${ }^{11}$ This interpretation is valid for all finally selected model specifications in this paper which do not include the full set of variables proposed by theory, i.e., by our Eqs. (1) and (2).

${ }^{12}$ In Section 3.2 we spared cointegration analysis because the time span 2000 to 2017 is much shorter than the one available in Section 3.1., i.e. 1970 to 2016. Note that using quarterly data (Section 3.2) instead of annual ones (Section 3.1) does not help, because integration and cointegration are sample (period) properties which are not necessarily dependent on the number of observations.
} 
equipment, rubber, optical instruments and paper. Our panel analysis with sectorspecific monthly data suggests that movements of the sector-specific real effective yen exchange rate had significant impact on up to seven industrial sectors (chemicals, optical instruments, rubber, wood, textiles, paper and transport equipment). Still, we should also mention that our ARDL and panel estimations did not uncover significant exchange rate effects for several industrial sectors, including general machinery, one of the most important industrial sectors for Japan.

From a policy perspective, our findings suggest that central banks should try to avoid rapid, large-scale appreciations of the type Japan has seen a number of times over recent decades as negative effects on the manufacturing sector cannot be easily reversed at a later stage. This would suggest that an exchange rate policy that seeks to moderate exchange movements - often referred to as "leaning against the wind" - may be more adequate than entirely freely floating rates, even for large, advanced economies. In fact, Japan followed such an exchange rate policy at times (e.g., Quirk 1977; Takagi 1991). However, given Japan has persistently recoded a large bilateral trade surplus vis-à-vis the US, it was repeatedly under heavy pressure from the US administration to let the yen appreciate against the US dollar - most notably in the run-up to the Plaza agreement. Foreign exchange interventions therefore became politicised and difficult to follow through. It is interesting to note that China for long resisted pressure from the US to let the renminbi appreciate - which arguably contributed to the malaise of Japan's manufacturing sector. Since ending its dollar peg, China has been cautious to allow only gradual appreciation of its currency.

Given the importance of the manufacturing sector for growth, development and employment, policy makers ought to consider potential adverse effects of rapid, largescale exchange rate appreciations. As pointed out by Frankel (1999), no single exchange rate regime is right for all countries or at all times. There can be therefore no general recommendations regarding the most appropriate exchange rate regime. But our findings suggest that the exchange rate is too important to be ignored by policy makers.

Acknowledgments Open Access funding provided by Projekt DEAL. The paper was written while the second author held the Banque de France Chair at EHESS in Paris. Ulrich Volz would like to thank Banque de France for financial support for this research project and Fondation France Japon de l'EHESS for its wonderful hospitality and great support. The authors are grateful for comments received by two anonymous referees, Kenji Aramaki, George Chortareas, Volker Clausen, Laurent Ferrara, Andy Filardo, Maurizio Habib, Benedicto Lukanima, Toshiyuki Matsuura, Volker Nitsch, Tobias Stöhr, Franz Waldenberger, Martin Weale and Naoyuki Yoshino and other participants at the 2nd Japan Economy Network Conference held at the Asian Development Bank Institute in Tokyo on 14-15 September 2017, the Banque de France-EHESS Workshop on "The Role of the Exchange Rate for the Real Economy - Experiences from Japan and the Europe" at Banque de France in Paris on 27 October 2017, an Economics Research Seminar at King's College in London on 14 March 2018, the International Conference on Macroeconomics and International Finance in Rethymno from 24 to 26 May 2018, the World Finance Conference in Mauritius from 25 to 27 July 2018, and the Annual Conference 2018 of the German Economic Association in Freiburg im Breisgau from 2 to 5 September 2018. We would also like to acknowledge very helpful comments and suggestions by Sébastien Lechevalier, Eiji Ogawa, Toshitaka Sekine and Wataru Takahashi during the research on this paper. We are also grateful to Tatsufumi Yamagata at IDE-JETRO for kindly providing us with industryspecific export data. The usual disclaimer applies. 


\section{Appendix}

Table 14 Variables and sources for analysis with annual data, 1970-2016

\begin{tabular}{|c|c|}
\hline Variable & Source \\
\hline $\begin{array}{l}E M P M A N=\text { Share of manufacturing in total number of employed } \\
\text { persons }(\%)\end{array}$ & $\begin{array}{l}\text { Japan Labor Force Survey, Statistics } \\
\text { Bureau }\end{array}$ \\
\hline$C A P=$ Gross domestic fixed capital formation ( $\%$ of GDP) & $\begin{array}{l}\text { World Bank World Development } \\
\text { Indicators }\end{array}$ \\
\hline$E X P M A N=$ Manufacturing exports & $\begin{array}{l}\text { World Bank World Development } \\
\text { Indicators }\end{array}$ \\
\hline$O F D I=$ Outward direct investment & $\begin{array}{l}\text { Japanese Trade and Investment Statistics, } \\
\text { JETRO }\end{array}$ \\
\hline$T F P=$ Total factor productivity at constant national prices & Penn World Table 9.0 \\
\hline$E X P C H I N=$ Chinese exports & $\begin{array}{l}\text { World Bank World Development } \\
\text { Indicators }\end{array}$ \\
\hline$E X R=$ Real effective exchange rate & Bank of Japan \\
\hline
\end{tabular}

Table 15 Variables and sources for analysis with monthly data, 1991-2017

\begin{tabular}{lc}
\hline Variable & Source \\
\hline$I N P \_X=$ Industrial production by industry X & METI Survey of Production \\
$E X \_X=$ Exports by industry X & Global Trade Atlas \\
REER_X= Industry-specific real effective exchange rate of industry X for 11 & Sato et al. (2013); RIETI \\
different industrial sectors and manufacturing as a whole & (2017) \\
INDINPUTPRICE = Industrial input price & IMF Primary Commodity \\
& Prices \\
INPUSA = Industrial production United States & World Bank Global \\
& Economic Monitor \\
\hline
\end{tabular}


Table 16 Industry classifications

\begin{tabular}{lll}
\hline ISIC.R3 & Industry name & Description \\
\hline $15-16$ & Food & Food, beverage and tobacco \\
$17-19$ & Textile & Textiles, textile products, leather and footwear \\
20 & Wood & Wood products (excl. furniture) \\
$21-22$ & Paper & Paper, paper products, printing, and publishing \\
23 & Petroleum & Coke, refined petroleum products, and nuclear fuel \\
24 & Chemicals & Chemicals and chemical products \\
25 & Rubber & Rubber and plastics products \\
29 & General machinery & Machinery and equipment \\
$30-32$ & Electrical equipment & Electrical machinery and apparatus \\
33 & Optical instruments & Optical and precision instruments \\
$34-35$ & Transport equipment & Transport equipment \\
\hline
\end{tabular}

Source: Sato et al. (2015)

Open Access This article is licensed under a Creative Commons Attribution 4.0 International License, which permits use, sharing, adaptation, distribution and reproduction in any medium or format, as long as you give appropriate credit to the original author(s) and the source, provide a link to the Creative Commons licence, and indicate if changes were made. The images or other third party material in this article are included in the article's Creative Commons licence, unless indicated otherwise in a credit line to the material. If material is not included in the article's Creative Commons licence and your intended use is not permitted by statutory regulation or exceeds the permitted use, you will need to obtain permission directly from the copyright holder. To view a copy of this licence, visit http://creativecommons.org/licenses/by/4.0/.

\section{References}

Alfaro L, Cuñat A, Fadinger H, Liu Y (2018) The real exchange rate, innovation and productivity: regional heterogeneity, asymmetries and hysteresis, NBER working paper no. 24633. National Bureau of Economic Research, Cambridge

Bahmani-Oskooee M, Mirzaie IA (2000) The long-run effects of depreciation of the dollar on sectoral output. Int Econ J 14(3):51-61

Bahmani-Oskooee M, Mirzaie IA, Miteza I (2007) Sectoral employment, wages and the exchange rate: evidence from the U.S. East Econ J 33(1):125-136

Baldwin RE (1990) Hysteresis in trade. Empir Econ 15(2):127-142

Baldwin RE (2006) Globalisation: the great unbundling(s). Paper contributed to the project Globalisation Challenges for Europe and Finland organised by the Secretariat of the Economic Council. http://citeseerx. ist.psu.edu/viewdoc/download?doi=10.1.1.511.95\&rep=rep1\&type=pdf

Baldwin RE, Krugman PR (1989) Persistent trade effects of large exchange rate shocks. Q J Econ 104(4):635654

Baldwin RE, Lyons RK (1994) Exchange rate hysteresis: large versus small policy misalignments. Eur Econ Rev 38(1):1-22

Belke A, Gros D (2001) Real impacts of intra-European exchange rate variability: a case for EMU? Open Econ Rev 12(3):231-264

Belke A, Kronen D (2019) Exchange rate bands of inaction and hysteresis in EU exports to the global economy - the role of uncertainty. J Econ Stud 46(2):335-355 
Belke A, Volz U (2015) The strong euro: challenges for the European Central Bank and implications for the global economy. AEI Insight 1(1):53-68

Belke A, Göcke M, Günther M (2013) Exchange rate bands of inaction and play-hysteresis in German exports - sectoral evidence for some OECD destinations. Metroeconomica 64(1):152-179

Bénassy-Quéré A, Gourinchas P-O, Martin P, Plantin G (2014) The Euro in the 'Currency War'. Policy Insights No. 70. Centre for Economic Policy Research, London

Berman N, Martin P, Mayer T (2012) How do Different Exporters React to Exchange Rate Changes?, The Quarterly Journal of Economics 127(1):437-492

Bleaney M (1997) Invoicing-currency effects in the pricing of Japanese exports of manufactures. Can J Econ 30(4a):968-974

Bloningen BA (1997) Firm-specific assets and the link between exchange rates and foreign direct investment. Am Econ Rev 87(3):447-465

BOJ (1989): "Balance of Payments Adjustment in Japan. Recent Developments and Prospects", Special Paper No. 178, Tokyo: Bank of Japan

BOJ (2011) Outlook for economic activity and prices, October. Bank of Japan, Tokyo

Boulhol H, Fontagné L (2006) Deindustrialisation and the fear of relocations in the industry, CEPII working paper no. 2006-07. Centre d'Etudes Prospectives et d'Informations Internationales, Paris

Branson WH, Love JP (1986) Dollar appreciation and manufacturing employment and output, NBER working paper no. 1986. National Bureau of Economic Research, Cambridge, MA

Branson WH, Love JP (1987) The real exchange rate and employment in U.S. manufacturing: state and regional results, NBER working paper no. 2435. National Bureau of Economic Research, Cambridge, MA

Branson WH, Love JP (1988a) The real exchange rate, employment, and output in manufacturing in the U.S. and Japan, NBER working paper no. 2491. National Bureau of Economic Research, Cambridge, MA

Branson WH, Love JP (1988b) U.S. manufacturing and the real exchange rate. In: Marston RC (ed) Misalignment of exchange rates: effects on trade and industry. University of Chicago Press, Chicago, pp 241-276

Breitung J (2000) The local power of some unit root tests for panel data. In: Baltagi BH (ed) Advances in econometrics, Vol. 15: Nonstationary panels, panel cointegration, and dynamic panels. JAI Press, Amsterdam, pp 161-178

Bussière M, Lopez C, Tille C (2015) Currency crises in reverse: do large real exchange rate appreciations matter for growth? Econ Policy 30(81):5-45

Campa JM (2004) Exchange rates and trade: how important is hysteresis in trade? Eur Econ Rev 48(3):527548

Campa JM, Goldberg LS (1995) Investment in manufacturing, exchange rates and external exposure. J Int Econ 38(3-4):297-320

Campa JM, Goldberg LS (2001) Employment versus wage adjustment and the US Dollar. Rev Econ Stat 83(3):477-489

Campbell DL (2017) Relative prices, hysteresis, and the decline of American manufacturing. New Economic School, Moscow Web: https://ideas.repec.org/p/cfr/cefirw/w0212.html

Choi I (2001) Unit root tests for panel data. J Int Money Financ 20(2):249-272

Dekle R (1996) Endaka and Japanese employment adjustment, Center on Japanese economy and business working papers no. 113. Graduate School of Business, Columbia University, New York

Dekle R, Fukao K, Ungor M (2010) The Japan-US exchange rate, productivity, and the competitiveness of Japanese industries. In: Hamada K, Kashyap AK, Weinstein DE (eds) Japan's bubble, deflation, and longterm stagnation. MIT Press, Cambridge, MA, pp 105-128

Ekholm K, Moxnes A, Ulltveit-Moe KH (2012) Manufacturing restructuring and the role of real exchange rate shocks. J Int Econ 86(1):101-117

Fort TC, Pierce JR, Schott PK (2018) New perspectives on the decline of US manufacturing employment. J Econ Perspect 32(2):47-72

Frankel JA (1999) No single currency regime is right for all countries or at all times, NBER working paper no. 7338. National Bureau of Economic Research, Cambridge, MA

Fukao K, Ishido H, Ito K (2003) Vertical intra-industry trade and foreign direct investment in East Asia. J Jpn Int Econ 17(4):468-506

Giovannetti G, Samiei H (1995) Hysteresis in exports, IMF working paper no. 95/52. International Monetary Fund, Washington, DC

Glick R, Hutchison MM (1990) Does exchange rate appreciation 'deindustrialize' the open economy? A critique of U.S. evidence. Econ Inq 28(1):19-37

Goldberg L (1993) Exchange rates and Investment in United States Industry. Rev Econ Stat 75(4):575-588 
Gourinchas P-O (1999) Exchange rates and jobs: what do we learn from job flows? In: Bernanke BS, Rotemberg J (eds) NBER macroeconomics annual 1998, vol 13. MIT Press, Cambridge, pp 153-222

Greene WH (2008) Econometric analysis, 6th edn. Prentice-Hall, Upper Saddle River

Hadri K (2000) Testing for stationarity in heterogeneous panel data. Econ J 3(2):148-161

Hamada K, Okada Y (2009) Monetary and international factors behind Japan's lost decade: from the plaza accord to the great intervention. J Jpn Int Econ 23(2):200-219

Im KS, Hashem Pesaran M, Shin Y (2003) Testing for unit roots in heterogeneous panels. J Econ 115(1):5374

Kandil M, Mirzaie IA (2002) Exchange rate fluctuations and disaggregated economic activity in the US. Theory and evidence. J Int Money Financ 21(1):1-31

Kandil M, Mirzaie IA (2003) The effects of dollar appreciation on sectoral labor market adjustments: theory and evidence. Q Rev Econ Financ 43(1):89-117

Kappler M, Reisen H, Schularick M, Turkisch E (2013) The macroeconomic effects of large exchange rate appreciations. Open Econ Rev 24(3):471-494

Kato A (2018) Exports, exchange rates, and productivity: an analysis of the japanese manufacturing sectors, RIETI discussion paper no. 16-E-045. The Research Institute of Economy, Trade and Industry, Tokyo

Klein MW, Schuh S, Triest RK (2003) Job creation, job destruction, and the real exchange rate. J Int Econ 59(2):239-265

Krugman PR (1988) Deindustrialization, reindustrialization, and the real exchange rate, NBER working paper no. 2586. National Bureau of Economic Research, Cambridge

Krugman PR, Baldwin R (1987) The persistence of the US trade deficit. Brook Pap Econ Act 1:1-43

Lawrence RZ (2017) Recent manufacturing employment growth: the exception that proves the rule, NBER working paper no. 24151. National Bureau of Economic Research, Cambridge

Levin A, Lin C-F, Chu C-SJ (2002) Unit root tests in panel data: asymptotic and finite-sample properties. J Econ 108(1):1-24

Levinson M (2017) U.S. manufacturing in international perspective. Congressional Research Service, Washington, DC

Levy-Yeyati E, Sturzenegger F, Gluzmann PA (2013) Fear of appreciation. J Dev Econ 101(C):233-247

MacKinnon JG, White H (1985) Some heteroskedasticity consistent covariance matrix estimators with improved finite sample properties. J Econ 29(3):305-325

Maddala GS, Wu S (1999) A comparative study of unit root tests with panel data and a new simple test. Oxf Bull Econ Stat 61(S1):631-652

METI (2018): Yearbook of Current Production Statistics, Tokyo: Ministry of Economy, Trade and Industry

Moser C, Urban D, Weder B (2010) International competitiveness, job creation and job destruction - an establishment-level study of German job flows. J Int Econ 80(2):302-317

Newey W, West K (1987) A simple positive semi-definite, heteroskedasticity and autocorrelation consistent covariance matrix. Econometrica 55(3):703-708

Obstfeld M (2010) Time of troubles: the yen and Japan's economy, 1985-2008. In: Hamada K, Kashyap AK, Weinstein DE (eds) Japan's bubble, deflation, and long-term stagnation. MIT Press, Cambridge

Quirk PJ (1977) Exchange rate policy in Japan: leaning against the wind. IMF Staff Pap 24(3):642-664

Revenga AL (1992) Exporting jobs? The impact of import competition on employment and wages in U.S. manufacturing. Q J Econ 107(1):255-284

RIETI (2018) Industry-specific nominal and real effective exchange rates of 25 countries worldwide. Web: www.rieti.go.jp/users/eeri/en/

Rodrik D (2008) The real exchange rate and economic growth: theory and evidence. Brook Pap Econ Activ 39(Fall):365-412

Rowthorn R, Coutts K (2004) De-industrialisation and the balance of payments in advanced economies. Camb J Econ 28(5):767-790

Rowthorn R, Coutts K (2013) De-industrialisation and the balance of payments in advanced economies, Centre for business research working paper no. 453. University Of Cambridge, Cambridge

Rowthorn R, Ramaswamy R (1997a) Deindustrialization: causes and implications, IMF working paper no. 97/ 42. International Monetary Fund, Washington, DC

Rowthorn R, Ramaswamy R (1997b) Deindustrialization: causes and implications, IMF economic issues no. 10. International Monetary Fund, Washington, DC

Ryan MJ, Toubal F (2017) Hollowing out of the Japanese economy: a long-term perspective. In: Fontagné L, Harrison A (eds) The factory-free economy: outsourcing, servitization, and the future of industry. Oxford University Press, Oxford

Saikkonen P (1992) Estimation and testing of cointegrated systems by an autoregressive approximation. Econ Theory $8(1): 1-27$ 
Sato K, Shimizu J, Shrestha N, Zhang S (2013) Industry-specific real effective exchange rates and export price competitiveness: the cases of Japan, China, and Korea. Asian Econ Policy Rev 8(2):298-321

Sato K, Shimizu J, Shrestha N, Zhang S (2015) Industry-specific real effective exchange rates in Asia, RIETI discussion paper no. 15-E-036. Research Institute of Economy, Trade, and Industry, Tokyo

Stock JH, Watson M (1993) A simple estimator of cointegrating vectors in higher order integrated systems. Econometrica 61(4):783-820

Takagi S (1991) Foreign exchange market intervention and domestic monetary control in Japan, 1973-1989. Japan World Econ 3(2):147-180

Thorbecke W (2012) The short- and long-run effects of exchange rate changes on the Japanese electronics industry, RIETI discussion paper no. 12-E-019. Research Institute of Economy, Trade, and Industry, Tokyo

Thorbecke W, Kato A (2017) Exchange rates and the Swiss economy, RIETI discussion paper no. 17-E-064. Research Institute of Economy, Trade, and Industry, Tokyo

Uemura H, Tahara S (2014) The transformation of growth regime and de-industrialization in Japan. Revue de la régulation 15(1). https://doi.org/10.4000/regulation.10777 http://journals.openedition. org/regulation/10777

White H (1980) A heteroskedasticity-consistent covariance matrix and a direct test for heteroskedasticity. Econometrica 48(4):817-838

Wooldridge JM (2009) Introductory econometrics: a modern approach, 4th edn. South-Western College Publishing, Cincinnati

Yamashita T (2013) Exchange rates and deindustrialization: Japanese experiences. Shizuoka University, Mimeo

Yamashita T (2015) Exchange rates and reshoring. Mimeo. Web: www.systemdynamics.org/conferences/2015 /papers/P1146.pdf

Yamashita N, Fukao K (2010) Expansion abroad and jobs at home: evidence from Japanese multinational enterprises. Japan World Econ 22(2):88-97

Publisher's Note Springer Nature remains neutral with regard to jurisdictional claims in published maps and institutional affiliations.

\section{Affiliations}

\section{Ansgar Belke ${ }^{1,2,3,4} \cdot$ Ulrich Volz ${ }^{5}$}

1 University of Duisburg-Essen, Essen, Germany

2 CEPS, Brussels, Belgium

3 IZA, Bonn, Germany

4 King's College London, London, UK

5 Department of Economics, SOAS University of London, London, UK 